\title{
Striving for Consistency: Why German Sentencing Needs Reform
}

\author{
Clara Herz
}

(Received 20 February 2020; revised 02 May 2020; accepted 03 May 2020)

\begin{abstract}
Given the debate at the seventy-second Conference of the Association of German Jurists (Deutscher Juristentag) in September 2018 on whether German sentencing needs reform, this Article will explore this very question in greater detail. In this regard, this Article will present various empirical studies in order to demonstrate that notable inconsistencies in German sentencing practice exist. This Article will then point out that broad statutory sentencing ranges, along with fairly vague sentencing guidance, are among the main causes of these disparities. Subsequently, this Article will examine several mechanisms that selected foreign jurisdictions - namely the U.S., the U.K., and Australia-have put in place in order to enhance consistency in their sentencing practices. Three mechanisms of sentencing guidance will be distinguished here: First, formal sentencing guidelines; second, guideline judgments; and third, sentencing advisory bodies as they operate in some Australian states. This Article will compare these mechanisms and assess their merits and drawbacks. Based on this comparative study, this Article will look at how to improve consistency in German sentencing practice. In this respect, this Article will present three steps that German criminal law reform should follow, including a better sentencing framework, the strategic gathering of sentencing data, and the implementation of a flexible sentencing guidelines regime.
\end{abstract}

Keywords: Criminal Justice; criminal law; sentencing guidelines; guideline judgments; sentencing information systems

\section{A. Introduction}

In March 2020, North Rhine-Westphalia was the first German state to issue detailed guidelines on the determination of fines for violations of its newly established coronavirus restrictions. In the weeks that followed, many other German states like Bavaria, Berlin, and Brandenburg issued similar guidelines that set out precise amounts, or at least narrow ranges, of possible fines for coronavirus misdemeanors. ${ }^{1}$

This development is noteworthy and striking because guidelines for the determination of fines are extremely rare in Germany. Apart from the coronavirus guidelines, there are very few areas of German law where detailed sentencing catalogs exist-one of these are the guidelines for sentencing road traffic misdemeanors that are laid out in a particular sentencing manual

${ }^{\star}$ LL.M. Graduate, Trinity College Dublin, Ireland; Ph.D. Candidate, University of Passau, Germany. The author would like to thank Dr. David Prendergast (Trinity College Dublin) as well as Prof. Dr. Robert Esser and Dr. Oliver Gerson (both University of Passau) for their valuable comments and advice.

${ }^{1}$ For an up-to-date overview of the various coronavirus guidelines existing in the German states, see Übersicht COVID19_VO der Länder, BUNDESRECHTSANWALTSKAMMER, https://brak.de/die-brak/coronavirus/uebersicht-covid19voder-laender/ (last visited Oct. 14, 2020).

(c) The Author(s), 2020. Published by Cambridge University Press on behalf of the German Law Journal. This is an Open Access article, distributed under the terms of the Creative Commons Attribution licence (http://creativecommons.org/licenses/by/4.0/), which permits unrestricted re-use, distribution, and reproduction in any medium, provided the original work is properly cited. 
(Bußgeldkatalog). ${ }^{2}$ This manual only applies to misdemeanors under Section 24 of the German Road Traffic Act (Straßenverkehrsgesetz [StVG]) according to which road traffic misdemeanors are punishable with a monetary fine of "up to $2,000 €$ "3. By using a grid, the manual sets out precise sanctions for particular kinds of road traffic misdemeanors. However, the manual is not binding upon the judiciary. It only provides some "orientation" for criminal judges. ${ }^{4}$ In this regard, German courts have continuously held that judges were not allowed to refer directly to the grid-based sentencing level ${ }^{5}$ because doing so would represent an unduly schematic approach to finding a sentence. ${ }^{6}$

This long-standing jurisprudence illustrates that the German criminal justice system values judicial discretion. On a broader level, this is also reflected by the fact that Germany has not yet adopted a structured approach to sentencing apart from Section 46 of the German Criminal Code (Strafgesetzbuch [StGB]). This provision gives judges at least some guidance when they face the crucial decision of determining a criminal sentence. In general, however, sentencing under German criminal law remains a "reaching into the dark" (Griff ins Dunkle), as Franz von Liszt famously described it. ${ }^{7}$

In contrast, many foreign jurisdictions have implemented detailed guidance on sentencing over the last decades. The most prominent examples in this regard are the numerical guidelines used in the U.S. that seek to achieve uniformity in sentencing and, therefore, promote consistency of sentencing outcomes. ${ }^{8}$ England, Wales, Scotland, and Northern Ireland have also implemented some kind of formal sentencing guidelines in order to structure judicial discretion. ${ }^{9}$ Many Australian states have taken measures in this regard as well. ${ }^{10}$ Furthermore, jurisdictions like China, ${ }^{11}$ South

\footnotetext{
${ }^{2}$ For the latest version of the manual, see Bußgeldkatalog-Verordnung [BKatV] [Catolog of Fines Ordinance], Mar. 14, 2013, BCBL I at 498 (Ger.), https://www.gesetze-im-internet.de/bkatv_2013/BJNR049800013.html. Other existing sentencing manuals are compiled at BUßGELDKATALOG, https://www.bussgeldkatalog.org/ (last visited Oct. 14, 2020). In this regard, also note the sentencing manual issued by the German Conference of Independent Federal and State Data Protection Authorities (Datenschutzkonferenz) on the determination of fines under Article 83 GDPR: DATENSCHUTZKONFERENZ, KONZEPT DER UNABHÄNGIGEN DATENSCHUTZAUFSICHTSBEHÖRDEN DES BUNDES UND DER LÄNDER ZUR BUßGELDZUMESSUNG IN VERFAHREN GEGEN UNTERNEHMEN (Oct. 14, 2019), https://www.datenschutzkonferenz-online.de/media/ah/20191016_bu\% C3\%9Fgeldkonzept.pdf.

${ }^{3}$ Straßenverkehrsgesetz [StVG] [German Road Traffic Act], $₫ 24$, https://www.gesetze-im-internet.de/stvg/_24.html (Ger.).

${ }^{4}$ For example, see Oberlandesgericht [OLG] [High Regional Court] May 31, 2000, Neue ZeITSCHRIFt FÜr VerKeHrSRECHT [NZV] 425 (Ger.); Oberlandesgericht [OLG] [High Regional Court] Sept. 3, 2004, Deutsches Autorecht [DAR] 712.

${ }^{5}$ Bayerisches Oberstes Landesgericht [BayObLG] [Bavarian Higher Regional Court], Case No. 1 b Ws (B) 27/69 (Aug. 1, 1969); Oberlandesgericht [OLG] [High Regional Court], Case No. 1 Ws (OWi) 510/69 (Aug. 18, 1969); Oberlandesgericht [OLG] [High Regional Court] Hamburg, Jan. 23, 2007, BeCK-RechtsPechung 03188; Oberlandesgericht [OLG] [High Regional Court] Hamburg, Mar. 24, 2009, BECK-RechtsPeCHung 12027; Oberlandesgericht [OLG] [High Regional Court] Hamburg, Sept. 29, 2016, BeCK-ReChtspechung 18440.

${ }^{6}$ See Oberlandesgericht [OLG] [High Regional Court] Koblenz, Aug. 26, 2011, VerkehrsRechtsReport [VRR] 470; Oberlandesgericht [OLG] [High Regional Court] Düsseldorf, Nov. 12, 2010, Neue ZeITsChrift FÜr VerKeHrSRECHT 49 (2011). See also Oberlandesgericht [OLG] [High Regional Court] Hamburg, Sept. 18, 1963, NeUE JURISTISCHE Wochenschrift [NJW] 2387; Oberlandesgericht [OLG] [High Regional Court] Köln, Dec. 17, 1965, NeUE JURISTISCHE WOCHENSCHRIFT [NJW] 895 (1966).

${ }^{7}$ Franz von Liszt, Strafrechtliche Aufsätze und Vorträge 393 (1905). Quoted, inter alia, by Franz Streng, Perspektiven für die Strafzumessung, 38 STRAFVERTEIDIGER 593 (2018).

${ }^{8}$ See Sarah Krasnostein \& Arie Freiberg, Pursuing Consistency in an Individualistic Sentencing Framework: If You Know Where You're Going, How Do You Know When You've Got There?, 76 LAW \& ConTemP. Probs. 265, 271 (2013).

${ }^{9}$ Research and Infromation Service (RaISE), Sentencing Guidelines Mechanisms in Other Jurisdictions, N. IR. AsSEMBLY NIAR 195-16, 7, 22 (2016), http://www.niassembly.gov.uk/globalassets/documents/raise/publications/2016-2021/2016/ justice/7916.pdf.

${ }^{10}$ See Krasnostein \& Freiberg, supra note 8, at 273.

${ }^{11}$ See Xiaoming Chen, The Chinese Sentencing Guideline: A Primary Analysis, 22 Fed. SENT'G ReP. 213 (2010); Julian V. Roberts \& Wei Pei, Structuring Judicial Discretion in China: Exploring the 2014 Sentencing Guidelines, 27 CRIM. L.F. 3 (2016).
} 
Korea, ${ }^{12}$ Singapore ${ }^{13}$ Indonesia, ${ }^{14}$ and Kenya ${ }^{15}$ have also adopted, or at least discussed, mechanisms that aim at structuring judicial discretion.

Consistency in sentencing means that similar cases should be treated alike, and unwarranted disparities in sentencing should not exist. ${ }^{16}$ This idea is not new; rather, it emerged in the eighteenth century in the course of the enlightenment movement. ${ }^{17}$ Today, legislation in New Zealand and Canada even recognizes consistency as a sentencing principle that judges must take into account. ${ }^{18}$ In Germany, however, consistency is not perceived as a sentencing principle. Rather, the German Constitution only protects against arbitrary sentencing considerations as the German Federal Constitutional Court (Bundesverfassungsgericht [BVerfG]) has held. ${ }^{19}$ Accordingly, the principle of equality-enshrined in Article 3 of the German Constitution-will only be violated if a judge cannot provide a legitimate explanation for a sentencing variation. ${ }^{20}$ This implies that a criminal offender cannot challenge his sentence by arguing that his case should be decided the same way as another criminal's case, as long as his own case was decided in accordance with the law. ${ }^{21}$

This Article will demonstrate that a weak level of constitutional protection in these cases is problematic because there are significant inconsistencies in German sentencing practice. Sentencing not only depends on the judge who decides the case, but it also varies to a remarkable extent across German court districts and regions. ${ }^{22}$ Against this backdrop, this Article will join a discussion that recently attracted broader attention as it reemerged at the seventy-second Conference of the Association of German Jurists (Deutscher Juristentag) ${ }^{23}$ in September 2018,

\footnotetext{
${ }^{12}$ See Hyungkwan Park, The Basic Features of the First Korean Sentencing Guidelines, 22 FED. SENT'G ReP. 262 (2010).

${ }^{13}$ See Amardeep Singh \& Gurcharan Singh, Sentencing Reform in Singapore: Are the Guidelines in England and Wales a Useful Model?, 30 Sing. ACAD. L.J. 175 (2018); Benny Tan Zhi Peng, Assessing the Effectiveness of Sentencing Guideline Judgments in Singapore Issued Post-March 2013 and a Guide to Constructing Frameworks, 30 SING. ACAD. L.J. 1004 (2018).

${ }^{14}$ See Rifqi S. Assegaf, Sentencing Guidance in the Indonesia's Criminal Code Reform Bill: For Whose Benefit?, 19 AUSTL. J. Asian L. 1 (2018).

${ }^{15}$ See Harrison Mbori Otieno, Discreet Discretion and Moderate Moderation in Judicial Sentencing: A Commentary on Kenya's Sentencing Policy Guidelines, 2016, 3 Strathmore U.L.J. 89 (2017); see also Sarah Muringa Kinyanjui \& Migai Akech, Towards Structured Sentencing in Kenya: A Case for Reform, 9 AFr. J. CRIMINOLOGY \& JUST. STUD. 266 (2016).

${ }^{16}$ For further details on sentencing equality, see James Q. Whitman, Equality in Criminal Law: The Two Divergent Western Roads, 1 J. LEgal ANALYsis 119 (2009).

${ }^{17}$ See Ivana Bacik, The Courts: Consistent Sentencing?, 88 IRISH Q. ReV. 164 (1999).

${ }^{18} \mathrm{See}$ New Zealand Sentencing Act 2002, s 8(e) ("In sentencing or otherwise dealing with an offender the court must take into account the general desirability of consistency with appropriate sentencing levels and other means of dealing with offenders in respect of similar offenders committing similar offences in similar circumstances."); see also Criminal Code, R.S.C. 1985, c C-46, s 718.2(b) (Can.) ("A court that imposes a sentence shall take into consideration ... [that] ... a sentence should be similar to sentences imposed on similar offenders for similar offences committed in similar circumstances.").

${ }^{19} \mathrm{See}$ Bundesverfassungsgericht [BVerfG] [Federal Constitutional Court] Oct. 23, 1951, 1 BundesverGassungsGe RICHTENTSCHEIDUNG [BVERFGE] 14, 1951 (Ger.); Bundesverfassungsgericht [BVerfG] [Federal Constitutional Court] Apr. 8, 1987, 75 BundesvergassungsGerichtentsCHEIDUNG [BVERFGE] 108, 1987 (Ger.); Bundesverfassungsgericht [BVerfG] [Federal Constitutional Court] June 13, 2006, 116 BundesvergassungsGerichtenTSCHEIDUNG [BVERFGE] 135, 2006 (Ger.).

${ }^{20} C f$. Frank Meyer, Discretion, in The Oxford Handbook of Criminal Law 913, 923 (Markus D. Dubber \& Tatjana Hörnle eds., 2014); Richard A. Bierschbach \& Stephanos Bibas, What's Wrong With Sentencing Equality?, 102 VA. L. REV. 1447, 1515 (2016).

${ }^{21}$ See Bundesverfassungsgericht [BVerfG] [Federal Constitutional Court] 2 BvR 294/98 (Mar. 19, 1998), https://www. bundesverfassungsgericht.de/SharedDocs/Entscheidungen/DE/1998/03/rk19980319_2bvr029498.html; see also Wolfgang Frisch, From Disparity in Sentencing Towards Sentencing Equality: The German Experience, 28 CRIM. L.F. 437, 445 (2017). Disparity in sentencing might also raise issues under the European Convention on Human Rights, art. 3, Nov. 4, 1950 and the Charter of Fundamental Rights of the European Union, art. 49, para. 3, Dec. 18, 2000, 2000 O.J. (C 364 ) 8. These questions merit a separate examination and shall not be discussed any further here.

${ }^{22}$ For details, see infra subsection $\mathrm{B}(\mathrm{I})$.

${ }^{23}$ The Association of German Jurists is a non-profit organization with approximately 5,000 members from all legal professions across Germany. The association's biennial conferences typically attract high media interest and have proven highly important as a forum for law reform in the past. For further information, see Der Verein-Über uns, DEUTSCHER JURISTENTAG, https://www.djt.de/djt-e-v/der-verein/ueber-uns/ (last visited Oct. 14, 2020).
} 
where Johannes Kaspar presented his expert opinion on whether German sentencing needs reform. ${ }^{24}$

Therefore, this Article seeks to answer the question how Germany should reform its criminal justice system in order to make sentencing more consistent and just. In answering this question, this Article will begin with an analysis of sentencing disparities as a phenomenon. In this regard, this Article will present various empirical studies that demonstrate inconsistencies in German sentencing practice, and it will explore the causes of these disparities. Subsequently, this Article will examine several mechanisms that selected foreign jurisdictions-namely the U.S., the U.K., and Australia-have put in place in order to enhance consistency in their sentencing practices. Three mechanisms of sentencing guidance will be distinguished here: First, formal sentencing guidelines; second, guideline judgments; and third, sentencing advisory bodies as they operate in some Australian states. This Article will compare these mechanisms and assess their merits and drawbacks. Based on this comparative study, this Article will look at how to improve consistency in German sentencing practice. In this respect, this Article will present three steps that German criminal law reform should follow, including a better sentencing framework, the strategic gathering of sentencing data, and the implementation of a flexible sentencing guidelines regime.

\section{B. Sentencing Disparity in Germany: Understanding the Phenomenon}

In order to gain a deeper understanding of sentencing disparity as a phenomenon in German sentencing practice, the following section will present various empirical studies on this topic. As the analysis will show, sentencing disparities represent a serious issue. Based on this finding, this Article will explore what causes these disparities.

\section{Empirical Studies on Disparities in German Sentencing Practice}

Back in 1874-only a few years after the first German Federal Criminal Code (Reichsstrafgesetzbuch [RStGB]) had entered into force-Medem noted that uncertainty and disparity reigned in sentencing practices under the newly established criminal code. ${ }^{25}$ In the decades that followed, many other sentencing practitioners and scholars expressed, in a similarly critical way, that they had observed remarkable disparities in German sentencing practice. ${ }^{26}$ However, these statements only express personal experiences, ${ }^{27}$ which is why researchers have begun to study sentencing disparities more systematically. Some of their studies deal with inter-judge disparities, while others focus on disparities that exist on a broader geographical level.

\section{Inter-Judge Disparities}

Inter-judge disparities concern differences in sentencing between individual judges. A study conducted by the German criminologist Franz Streng found that judges at regional courts (Landgerichte) tend to impose harsher sentences than judges at district courts (Amtsgerichte). ${ }^{28}$

\footnotetext{
${ }^{24}$ See Johannes Kaspar, Gutachten C Zum 72. Deutschen Juristentag: Sentencing Guidelines Versus Freies Tatrichterliches ERmessen-Brauchen Wir Ein Neues StrafZumessungsrecht? (2018). Discussed inter alia by Hans Kudlich \& Jennifer Koch, Das Ringen um die richtige Strafzumessung, 71 NeuE JuRISTISCHE WoCHENSCHRIFT 2762 (2018); Streng, supra note 7, at 593; Torsten Verrel, Brauchen wir ein neues Strafzumessungsrecht?, 73 JURISTENZEITUNG 811 (2018); Thomas Grosse-Wilde, Brauchen wir ein neues Strafzumessungsrecht?, 14 ZEITSCHRIFT FÜr INTERNATIONALE STRAFRECHTSDOGMATIK 130 (2019).

${ }^{25}$ R. Medem, Über Strafzumessung und Strafmaß, 26 Der Gerichtssaal 590, 591 (1874).

${ }^{26}$ For a summary of these observations, see Frisch, supra note 21, at 438.

${ }^{27}$ See Franz Streng, Strafzumessung Und Relative GerechtigKeit, 5 (1984); Frisch, supra note 21, at 439.

${ }^{28}$ STRENG, supra note 27 , at 131.
} 
Moreover, his study showed that sentencing varies between judges who favor the retributive purpose of criminal punishment and those who favor rehabilitation. ${ }^{29}$ Another study on disparities in German sentencing practice revealed that judges are not even consistent with their own previous judgments. ${ }^{30}$ Observations of real cases have shown that judges sometimes, without being aware of it, significantly depart from their previous assessment of a case that they had already decided in the past. $^{31}$

\section{Regional Disparities}

Another kind of disparity concerns differences in sentencing depending on where a case is decided geographically. The first empirical study that demonstrated the existence of regional disparities in German sentencing practice was published in 1907.32 Two decades later in 1931, Franz Exner found in his landmark study that significant variations in the harshness of criminal sentences existed between the judicial districts of the German Reich at that time. ${ }^{33}$ Particularly, his study revealed that criminal judges in Hamburg were punishing theft four times more severely than their colleagues in Stuttgart. ${ }^{34}$ Since then, several empirical studies have shown that regional disparities in sentencing still exist today. ${ }^{35}$

The most recent study on this topic was published in $2018 .^{36}$ This study was conducted by Volker Grundies, who used data of the German Federal Central Register (Bundeszentralregister) and examined which criminal sanctions had been imposed on adult offenders by German criminal courts in 2004, 2007, and 2010. ${ }^{37}$ On this basis, while examining an impressive dataset of more than 1.5 million court decisions, Grundies demonstrated the existence of remarkable geographical variations in German sentencing practice.

Overall, Grundies' study revealed two things: First, sentencing tends to be rather mild in Baden-Württemberg, which is located in the southwest of Germany, and in large parts of northern Germany; by comparison, southern Bavaria seems to exhibit a fairly harsh sentencing practice. ${ }^{38}$ Second, Grundies found that relatively mild sentencing levels existed in $17.5 \%$ of all German court districts, whereas relatively harsh sentencing levels dominated $21 \%$ of all German court districts. ${ }^{39}$ Although these variations appear within a range that some might classify as tolerable, ${ }^{40}$ this Article argues that these variations are remarkable and raise the question of whether it is fair that criminal

\footnotetext{
${ }^{29} I d$. at 226.

${ }^{30}$ See Robert M. McFatter, Ungleichheiten in der Strafzumessung und Zweck der Strafe, in STRAFZUMESSUNG: EMPIRISCHE Forschung und Strafrechtsdogmatik im Dialog 183, 190 (Christian Pfeiffer \& Margit Oswald eds., 1989).

${ }^{31}$ See 1 Karl Peters, Fehlerquellen im Strafprozess 7, 148 (1970).

${ }^{32}$ See Otto Woerner, Die Frage der Gleichmässigkeit der Strafzumessung im Deutschen Reich (1907).

${ }^{33}$ Franz Exner, Studien Über die StrafZumessungspraxis der DEUTSChen Gerichte (1931).

${ }^{34}$ Id. at 49.

${ }^{35}$ Christian Pfeiffer \& Joachim Savelsberg, Regionale und altersgruppenbezogene Unterschiede der Strafzumessung, in StrafZumessung: EMPIRISCHE Forschung und STRAFrechtSDOGMATIK IM Dialog, supra note 30 at 17; HANS-Jörg Albrecht, Strafzumessung BeI SCHWERER Kriminalität 348 (1994); Wolfgang LANger, StaAtSANWÄlte und

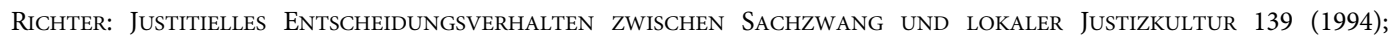
Margit Oswald, Psychologie Des Richterlichen Strafens 169 (1994). For an overview of existing studies on the subject, see KASPAR, supra note 24, at 19; Frisch, supra note 21, at 439.

${ }^{36}$ Volker Grundies, Regionale Unterschiede in der gerichtlichen Sanktionspraxis in der Bundesrepublik Deutschland: Eine empirische Analyse, in KRIMINAlSOZIOlOGIE 295 (Dieter Hermann \& Andreas Pöge eds., 2018).

${ }^{37}$ For his previous study based on data of 2004 and 2007, see Volker Grundies, Gleiches Recht für alle? - Eine empirische Analyse lokaler Unterschiede in der Sanktionspraxis in der Bundesrepublik Deutschland, in KRISE-KRIMINALITÄTKRIMINOLOGIE 511 (Frank Neubacher \& Nicole Bögelein eds., 2016).

${ }^{38}$ Grundies, supra note 36 , at 303 .

${ }^{39} I d$. at 301 .

${ }^{40} \mathrm{Cf}$. Tatjana Hörnle, Moderate and Non-Arbitrary Sentencing Without Guidelines: The German Experience, 76 L. \& Contemp. Probs. 189, 202 (2013) (holding that "this phenomenon should not be exaggerated .... It would thus be incorrect to claim that there is highly disparate or even arbitrary sentencing as a consequence of the vague legal framework").
} 
offenders are sentenced differently solely because their trial takes place in southern or northern parts of Germany, for example.

\section{Exploring the Causes of Sentencing Disparity}

Having shown that notable disparities in German sentencing practice exist, the following section will explore their causes. As this Article will point out, broad statutory sentencing ranges combined with broad judicial discretion set a normative framework within which such disparities may arise.

\section{Broad Statutory Sentencing Ranges}

In German criminal law, each offense is equipped with a minimum and a maximum sentence prescribed by statute. ${ }^{41}$ For example, theft is punishable with a monetary fine or imprisonment for up to five years. ${ }^{42}$ Robbery, on the other hand, is punishable with imprisonment of at least one year up to fifteen years. ${ }^{43}$

Broad sentencing ranges like these are not an exception. In fact, the vast majority of criminal offenses in Germany exhibit broad statutory sentencing ranges. ${ }^{44}$ In "very serious" or "less serious" cases, these already wide sentencing ranges may become even wider. For example, the statutory sentencing range for manslaughter-in its ordinary form-is imprisonment between five and fifteen years. ${ }^{45}$ Other sections of the StGB allow modifications in this regard so that punishment for manslaughter can range between one-year imprisonment, in the least serious cases, and life imprisonment, in the most serious cases. ${ }^{46}$

\section{Broad Judicial Discretion Within the Applicable Sentencing Range}

Once a judge has determined which statutory sentencing range is applicable in a particular case, Section $46 \mathrm{StGB}$ comes into play. This provision sets out several criteria for the determination of a criminal sentence and thereby provides judges with at least some sentencing guidance. However, the following analysis will show that Section $46 \mathrm{StGB}$ actually raises more questions than it answers. This Article will also point out that sentencing guidance given to appellate courts is fairly limited and, therefore, leaves German criminal judges with broad judicial discretion.

\subsection{Section 46 StGB: More Questions than Answers}

Soon after the enactment of Section 46 StGB in 1969, Günter Stratenwerth famously criticized this provision for being a "major legislative failure." ${ }^{47}$ Indeed, what gives rise to concerns about Section $46 \mathrm{StGB}$ is apparent from the wording of this provision, which reads as follows:

(1) The guilt of the offender is the basis for sentencing. The effects which the sentence can be expected to have on the offender's future life in society shall be taken into account.

(2) When sentencing the court shall weigh the circumstances in favor of and against the offender. Consideration shall in particular be given to the motives and aims of the offender,

\footnotetext{
${ }^{41}$ The only exception to this general rule concerns murder, which is exclusively punishable with life imprisonment, see STRAFGESETZBUCH [STGB] [Penal Code], $\$ 211$, https://www.gesetze-im-internet.de/englisch_stgb/englisch_stgb.html (Ger.).

${ }^{42} I d$. at $\$ 242(1)$.

${ }^{43} I d$. at $\$ \$ 249(1), 38(2)$.

${ }^{44}$ See KASPAR, supra note 24 , at 47.

${ }^{45}$ StrafgeSETZBUCH [STGB] [Penal Code], $\$ \$$ 212(1), 38(2), https://www.gesetze-im-internet.de/englisch_stgb/ englisch_stgb.html (Ger.).

${ }^{46} I d$. at $\$ \$ 212(2), 213$.

${ }^{47}$ See GÜNTER Stratenwerth, Tatschuld und StrafZumessung 13 (1972) ("gesetzgeberische Fehlleistung von besonderem Range.").
} 
especially when they are racist, xenophobic or in another respect inhuman; the attitude reflected in the offense and the degree of force of will involved in its commission; the degree of the violation of the offender's duties; the modus operandi and the consequences caused by the offense to the extent that the offender is to blame for them; the offender's prior history, his personal and financial circumstances; his conduct in the period following the offense, particularly his efforts to make restitution for the harm caused as well as the offender's efforts at reconciliation with the victim.

(3) Circumstances which are already statutory elements of the offense must not be considered. $^{48}$

Evident from its wording, Section 46 StGB does not answer the question about the purpose of criminal punishment with sufficient clarity. It only states that the offender's "guilt"- already an ambiguous term in itself-is the "basis" for sentencing. Likewise, Section 46 StGB remains unclear about the extent to which the effects on the offender's future life should be taken into account; it also does not specify the extent to which aspects of general prevention are relevant for the sentencing decision. ${ }^{49}$

Another issue with Section $46 \mathrm{StGB}$ is that it does not provide judges with further guidance on how they should arrive at a specific punishment after identifying and balancing the various circumstances mentioned in this provision. ${ }^{50}$ Moreover, Section 46 StGB remains unclear in terms of whether the criteria listed in the second sentence of Paragraph 2 should operate as aggravating or mitigating factors. ${ }^{51}$ In his expert opinion, Kaspar even noted that some of the criteria in Section 46(2) StGB are redundant, and the catalog should therefore be revised. ${ }^{52}$

Section $46 \mathrm{StGB}$ is also flawed in that it does not state where a judge should start within the applicable statutory sentencing range. Should the judge start from the theoretical average case, which represents the average of all conceivable cases? Or should the judge compare his case with the case that most frequently occurs in practice $?^{53}$ Sometimes, different starting points yield significantly different outcomes: As criminological research has shown, this is because the theoretical average case is placed in the middle of the sentencing range, whereas the most frequently occurring case in practice typically indicates a starting point in the lower third of the statutory sentencing range. ${ }^{54}$

Over the past decades, literature and jurisprudence have fixed at least some of the flaws of Section 46 StGB by establishing the so-called "leeway theory" (Spielraumtheorie), which is now recognized as the prevailing theory in German sentencing. ${ }^{55}$ According to the "leeway theory"-in literature also referred to as the "margin of guilt theory" (Schuldrahmentheorie) ${ }^{56}$ — there is never only one precise sentence that would be correct in a particular case. ${ }^{57}$ Rather, a certain leeway of accurate

\footnotetext{
${ }^{48}$ Strafgesetzbuch [STGB] [Penal Code], $\$ 46$, last amended by Gazette [GVBL], June 12, 2015, BGBL I at 925 (Ger.).

${ }^{49}$ See Frisch, supra note 21, at 449. Given the lack of a clear statutory provision, the purpose of criminal punishment is extremely controversial among German sentencing scholars. See KASPAR, supra note 24, at 22. See TATJANA HöRnlE, Straftheorien 17 (2017); Bernd-Dieter Meier, Strafrechtliche SANKTionen 15 (4th ed. 2015). For an overview in English, see Markus D. Dubber, Theories of Crime and Punishment in German Criminal Law, 53 AM. J. COMPAR. L. 679, 696 (2005).

${ }^{50}$ See Frisch, supra note 21, at 450.

${ }^{51} I d$. at 449 . For further details on each of the criteria listed in STRAFGESETZBUCH [STGB] [Penal Code], $\$ 46(2)$ (Ger.), see MEIER, supra note 49, at 192.

${ }^{52}$ See KASPAR, supra note 24 , at 66.

${ }^{53}$ For a discussion of these theories, see KASPAR, supra note 24, at 50, 97; Hörnle, supra note 40, at 194.

${ }^{54}$ See KASPAR, supra note 24 , at 50.

${ }^{55}$ See MeIER, supra note 49, at 167.

${ }^{56}$ See Hans-Gerd Meine, Der Schuldrahmen in der Praxis der Strafzumessung, 14 NeUe ZeITSChrift FÜr STRAFRECHT 159, 162 (1994).

${ }^{57}$ Bundesgerichtshof [BGH] [Federal Court of Justice] Sept. 13, 1976, 27 ENTSCHEIDUNGEN DES BUNDESGERICHTSHOFES IN STRAFSACHEN [BGHST] 2 (Ger.).
} 
punishments exists within the statutory sentencing range. ${ }^{58}$ The scope of this leeway is determined on the basis of the offender's guilt, whereas preventive considerations come into play when determining the precise sentence within this range of guilt-compatible punishments. ${ }^{59}$

The virtue of the "leeway theory" is that it sets out a step-by-step approach in accordance with Section 46(1) StGB. ${ }^{60}$ Yet, it operates with extremely vague criteria, ${ }^{61}$ which has led Tatjana Hörnle to argue that the "leeway theory" does not even deserve to be described as a theory given its thin content. ${ }^{62}$ In fact, the "leeway theory" is based on the idea that it is possible to determine a framework of guilt-appropriate punishments; however, as long as there is no clear definition or consensus of what "guilt" actually means, the interpretation of this term will vary from judge to judge. ${ }^{63}$ It is also extremely difficult to review the application of the "leeway theory" in practice ${ }^{64}$ because judges are not required to lay down the precise margin of guilt in the reasoning of their judgments. ${ }^{65}$

\subsection{Limited Sentencing Guidance Through Appellate Courts}

In Germany, judges can also hardly rely on sentencing guidance issued by higher instance courts due to the standard of judicial review. According to the well-established case-law of the Federal Court of Justice (Bundesgerichtshof [BGH]), the attribution of punishment depends on a judge's very personal impression gained during the main trial; thus, appellate courts may not exercise full scrutiny or subject an imposed sentence to comprehensive judicial review. ${ }^{66}$ According to the Federal Court of Justice, appellate courts may only intervene if the trial court's sentencing considerations are flawed, if the trial court has not considered the recognized purposes of punishment, or if the imposed sentence does not fall within the "margin of guilt." ${ }^{\text {" }}$ The Federal Court of Justice has also stressed that the appellate courts may not review the sentence for "absolute correctness" and that they must accept the sentence imposed by the trial court in cases of doubt. ${ }^{68}$ Although this standard of judicial review respects the nature of the sentencing decision as a decision that is not a mere calculation process that could be verified to the full extent, ${ }^{69}$ it expresses a certain reluctance towards judicial review. Most importantly, the Federal Court of Justice-theoretically in a position to review sentencing practices across the country - only has limited capacity so that many cases are per se excluded from being reviewed by the highest court of the ordinary judiciary. ${ }^{70}$

In this regard, it is also important to add that the Federal Court of Justice is generally opposed to issuing guideline judgments that set out sentencing levels for particular categories of offenses. ${ }^{71}$

\footnotetext{
${ }^{58}$ Bundesgerichtshof [BGH] [Federal Court of Justice] Nov. 10, 1954, 7 ENTSCHEIDUNGEN DES BundESGERICHTSHOFES IN STRAFSACHEN [BGHST] 28 (Ger.); Bundesgerichtshof [BGH] [Federal Court of Justice] Aug. 24, 1982, Stragverteidiger [STV] 329, 1983 (Ger.); Bundesgerichtshof [BGH] [Federal Court of Justice] Oct. 23, 2002, 5 StR 392/02 (Ger.), http://juris. bundesgerichtshof.de/cgi-bin/rechtsprechung/document.py?Gericht=bgh\&Art=en\&nr=24534\&pos=0\&anz=1.

${ }^{59}$ See Franz Streng, Sentencing in Germany: Basic Questions and New Developments, 8 German L.J. 153, 155 (2007); Hörnle, supra note 40, at 194.

${ }^{60}$ Streng, supra note 59, at 158; see also Frisch, supra note 21, at 452 ("[P] rovides very important initial guidance in individual cases.").

${ }^{61}$ See Streng, supra note 59, at 156.

${ }^{62}$ See Hörnle, supra note 40, at 194.

${ }^{63}$ Streng, supra note 59 , at 157.

${ }^{64}$ See Tatjana Hörnle, Strafzumessungslehre im Lichte des Grundgesetzes, in DAS STRAFENDE GESETZ IM SOZIALEN RechtsstaAt 105, 122 (Eva Schumann ed., 2010); Hörnle, supra note 40, at 194.

${ }^{65}$ See Hörnle, supra note 40, at 156; Gerhard Schäfer et Al., Praxis der Strafzumessung, para. 1443 (2017).

${ }^{66} 27$ BGHST 2 (Ger.); Bundesgerichtshof [BGH] [Federal Court of Justice] Sept. 17, 1980, 29 EnTSCHEIDUNGEN DeS BuNDESGERICHTSHOFES IN STRAFSACHEN [BGHST] 319 (Ger.).

${ }^{67} 29$ BGHST 319 (Ger.); 1983 StV 329 (Ger.).

${ }^{68} 29$ BGHST 319 (Ger.); Bundesgerichtshof [BGH] [Federal Court of Justice] Jan. 13, 1977, Neue JuRISTISCHE WochensChrift [NJW] 639 (Ger.); 1983 StV 329 (Ger.).

${ }^{69} \mathrm{Cf}$. Bundesverfassungsgericht [BVerfG] [Federal Constitutional Court] Mar. 20, 2002, 105 Bundesvergas SUNGSGERICHTENTSCHEIDUNG [BVERFGE] 135 (Ger.).

${ }^{70}$ See Hörnle, supra note 40, at 193.

${ }^{71}$ For details on guideline judgments in the U.K. and Australia, see infra subsection C(I).
} 
Although the Federal Court of Justice has, in fact, issued guideline judgments on tax evasion ${ }^{72}$ and road car race offenses ${ }^{73}$ in the past, such guideline judgments were highly exceptional. ${ }^{74}$ Recently, the Federal Court of Justice even refused to give guidance on sentencing levels for breach of trust cases under Section 266 StGB. ${ }^{75}$ This illustrates the exceptional character of guideline judgments.

\section{Consequence: Local Justice Culture and Informal Sentencing Guidance}

What should have become clear from the foregoing observations is that German criminal law and jurisprudence leave judges with broad judicial discretion-a situation that leads to significant legal uncertainty. Specifically, young judges have no idea which sentence to impose given the wide statutory sentencing ranges and the vagueness of the "leeway theory". Therefore, judges have found a pragmatic way of coping with this issue: They simply ask colleagues for help. ${ }^{76}$ More experienced judges know which sentences are typically imposed by that court or in that region-hence, they know the local justice culture. ${ }^{77}$ At some German courts, this local justice culture is even laid down in unofficial sentencing tables—-known as "the local second code"-that provide judges with sentencing guidance. ${ }^{78}$ Geographical sentencing patterns, therefore, express this local justice culture that has evolved as a result of broad statutory sentencing ranges, the vagueness of Section $46 \mathrm{StGB}$, and the nonexistence of appellate sentencing guidance. ${ }^{79}$ Remaining inter-judge disparities, however, are an inevitable consequence of a system that allows for judicial discretion because discretion entails that sentencing varies from judge to judge. ${ }^{80}$

\section{Conclusion}

The above analysis has shown that remarkable disparities exist in German sentencing practice. Regional disparities are now well-documented. As this Article has argued, these disparities are mainly caused by broad statutory sentencing ranges along with fairly vague sentencing guidance. In order to cope with their broad judicial discretion, judges have found a pragmatic solution: They simply apply local standards. From a normative point of view, this raises the question of how one could align sentencing levels to become more consistent in Germany overall. Therefore, this Article will now turn to foreign jurisdictions in order to draw from experiences made abroad.

\section{Sentencing Guidance: Lessons to be Learned from Foreign Jurisdictions}

Over the past decades, many foreign jurisdictions have undertaken considerable efforts in order to limit unwarranted disparities in their sentencing practice. ${ }^{81}$ Observing these international developments raises the question of what Germany-and other countries where sentencing disparities

\footnotetext{
${ }^{72}$ Bundesgerichtshof [BGH] [Federal Court of Justice] Dec. 2, 2008, 53 ENTSCHEIDUNGEN Des BundesGERICHTSHOFES IN STRAFSACHEN [BGHST] 71 (Ger.); Bundesgerichtshof [BGH] [Federal Court of Justice] Feb. 7, 2012, 57 ENTSCHEIDUNGEN DES BundesGerichtshofes IN STRAFSACHEN [BGHST] 123 (Ger.).

${ }^{73}$ Bundesgerichtshof [BGH] [Federal Court of Justice] July 6, 2017, NEUE JURISTISCHE WOCHENSCHRIFT [NJW] 3011 (Ger.).

${ }^{74}$ See also Frisch, supra note 21, at 453.

${ }^{75} \mathrm{See} \mathrm{Bundesgerichtshof} \mathrm{[BGH]} \mathrm{Mar.} \mathrm{14,} \mathrm{2018,} \mathrm{NeUE} \mathrm{Juristische} \mathrm{WochENSCHRIFT} \mathrm{[NJW]} 2210$ (Ger.). For further details, see Thomas Grosse-Wilde, Richterrechtliche Strafzumessungsregeln für die Untreue?, 7 NEUE ZEITSCHRIFT FÜR WIRTSCHAFTS-, STEUER- UND UNTERNEHMENSSTRAFRECHT [NZWIST] 457 (2018).

${ }^{76}$ See Hörnle, supra note 64, at 121; see also Winfried Hassemer, Juristische Methodenlehre und Richterliche Pragmatik, 39 ReChTSTHEORIE 1, 17, 20 (2008).

${ }^{77}$ See Bernd-Dieter Meier, Regionale Justizkulturen in der Strafrechtspraxis: ein Problem für den Rechtsstaat?, in JustizvollzUg und StrafrechtsReform im BundesstaAt 31 (Axel Dessecker \& Rudolf Egg eds., 2011).

${ }^{78}$ KASPAR, supra note 24 , at 89.

${ }^{79} \mathrm{Cf}$. MEIER, supra note 49 , at 257.

${ }^{80}$ See KASPAR, supra note 24 , at 18 .

${ }^{81}$ For a comprehensive overview, see Fiona O’Connell, Comparative Research Into Sentencing Guidelines Mechanisms, N. IR. AsSEMBLY, NiAR 610-10 (2011), http://www.niassembly.gov.uk/globalassets/documents/raise/publications/2011/justice/6611. pdf.
} 
are witnessed ${ }^{82}$ - can potentially learn from these jurisdictions. Therefore, the following section will present various mechanisms of sentencing guidance that are currently used in the U.S., the U.K., and Australia. Although all of these jurisdictions are common law jurisdictions-whereas Germany is a civil law jurisdiction-the U.S., the U.K., and Australia are well-suited for a comparative evaluation because they use quite distinct mechanisms of sentencing guidance. ${ }^{83}$ As "legal transplants", these mechanisms can travel across jurisdictions-as long as one accepts that this might lead to a change in the meaning of a certain mechanism as it will become part of another jurisdiction in the light of which it must then be seen. ${ }^{84}$

As this Article seeks to point out which general characteristics a useful sentencing guidance mechanism should exhibit, the following comparative analysis will not proceed country by country but rather evaluate mechanism by mechanism. In this regard, this Article will distinguish between three mechanisms, namely: guideline judgments, which are used in the U.K. and Australia; formal sentencing guidelines, which are used in the U.S. and the U.K.; and sentencing advisory bodies, a unique feature of some Australian states.

\section{Guideline Judgments-Virtues and Limitations}

Guideline judgments, in their original form, are court decisions that set precedents and thereby go beyond the individual case on which the decision was made. As they provide judges with guidance in relation to how particular kinds of offenders or particular categories of offenses should be sentenced, guideline judgments represent a mechanism of sentencing guidance that is designed to achieve greater consistency in sentencing through the judiciary itself. ${ }^{85}$ In other words, they provide guidance "by judges, for judges." 86

In England and Wales, the first guideline judgments were handed down by the Court of Appeals in the 1970's in R. v. Willis, ${ }^{87}$ and R. v. Taylor, Roberts, and Simons, ${ }^{88}$ two cases that concerned the sentencing of sexual offenses. ${ }^{89}$ In the following, the then Lord Chief Justice began to issue more judgments that proposed sentencing levels for particular offenses—but, overall, such judgments remained relatively infrequent. ${ }^{90}$ In Northern Ireland, guideline judgments are far

\footnotetext{
${ }^{82}$ One of these countries is the Republic of Ireland. For a recent study on disparities in Irish sentencing practice, see Avril Margaret Brandon \& Michael O'Connell, Same Crime: Different Punishment? Investigating Sentencing Disparities Between Irish and Non-Irish Nationals in the Irish Criminal Justice System, 58 BRIT. J. CrIMINOLOGY 1127 (2018). In this regard, also note the contemporary debate on whether Irish sentencing needs reform: LAW REFORM COMMISSION, REPORT ON MANDATORY SENTENCES, LRC 108-2013 (2013), https://www.lawreform.ie/_fileupload/Reports/r108.pdf; Laura Cahillane, Need for Sentencing Guidelines in Ireland?, 23 IRISH CRIM. L.J. 11 (2013).

${ }^{83}$ For an analysis of how judicial decision-making in these jurisdictions works, see Mandeep K. Dhami, Ian K. Belton \& Jane Goodman-Delahunty, Quasirational Models of Sentencing, 4 J. ApPlied RsCH. Memory \& CogNition 239 (2015); Graeme Brown, Four Models of Judicial Reasoning in Sentencing, 3 IRISH JUd. STUd. J. 55 (2019).

${ }^{84}$ For further details on legal transplants, see Alan Watson, Legal Transplants: AN Approach to Comparative LaW (1974); Pierre Legrand, The Impossibility of Legal Transplants, 4 MAASTRICHT J. EUR. \& COMPAR. L. 111 (1997); Maria Beatrice Berna, On Legal Norms and Their Cultural Context: Some Observations Regarding Legal Transplants, 9 J.L. \& ADMIN. SCI. 169 (2018); Julio Carvalho, Law, Language, and Knowledge: Legal Transplants from a Cultural Perspective, 20 GERMAN L.J. 21 (2019).

${ }^{85}$ See John L. Anderson, Leading Steps Aright: Judicial Guideline Judgments in New South Wales, 16 CURRENT ISSUES CRIM. Just. 140, 142 (2004).

${ }^{86}$ Brown, supra note 83 , at 65 .

${ }^{87} \mathrm{R}$ v. Willis [1974] 60 AC 146 (Eng.).

${ }^{88} \mathrm{R}$ v. Taylor, Roberts, and Simons [1977] 64 AC 182 (Eng.).

${ }^{89}$ See Gavin Dingwall, The Court of Appeal and “Guideline” Judgments, 48 N. IR. LeGAL Q. 143 (1997); Tom O’Malley, Sentencing Values and Sentencing Structures, 3 Jud. Stud. Inst. J. 130, 147 (2003); H. M. Keating et AL., CRiminaL LAW 70 (2014).

${ }^{90}$ See Andrew Ashworth, Techniques of Guidance on Sentencing, 31 CrIM. L. REv. 519, 530 (1984); Andrew Ashworth \& Julian V. Roberts, The Origins and Nature of the Sentencing Guidelines in England and Wales, in SENTENCING GUIDELINES: Exploring THE ENGLish Model 1, 3 (Andrew Ashworth \& Julian V. Roberts eds., 2013).
} 
more recent and far more institutionalized. Here, the Lord Chief Justice's Sentencing Group, a judicial oversight committee established in 2012, considers Crown Court judgments for publication on the Lord Chief Justice's website. ${ }^{91}$ Similarly, the Scottish Court of Criminal Appeal can issue guideline judgments based on Sections 118(7) and 189(7) of the Criminal Procedure (Scotland) Act of 1995, which will subsequently be published on the Scottish Sentencing Council's website. ${ }^{92}$

A guideline judgment mechanism has also been established in New South Wales. Based on Sections 36 to $42 \mathrm{~A}$ of the Crimes (Sentencing Procedure) Act of 1999, ${ }^{93}$ the New South Wales Court of Criminal Appeal may issue guideline judgments to be taken into account by sentencing judges. This mechanism seeks greater consistency in sentencing and has successfully achieved this ambition, as evaluations have shown. ${ }^{94}$ In Victoria, however, a guideline judgment mechanism was created in 2004, but it took more than a decade until the first guideline judgment was finally handed down in Boulton v. The Queen in 2015. ${ }^{95}$

The reluctance seen in Victoria illustrates the main weakness of any guideline judgment mechanism: As guideline judgments need to be established by the judiciary in the context of particular cases, it can take an extremely long time for a sufficiently broad set of sentencing guidance to emerge. ${ }^{96}$ Guideline judgment mechanisms are also largely dependent upon the willingness of the judiciary to make use of their powers. This has become clear in Scotland where judges have shown remarkable reluctance towards guideline judgments. ${ }^{97}$ Therefore, guideline judgments do not necessarily represent a mechanism that attracts broad acceptance from the judiciary, although one might expect that it would. ${ }^{98}$

Moreover, guideline judgments may lack the needed clarity. For example, the early guideline judgments in England and Wales only indicated starting points for a criminal sentence, but they did not set out-in precise numerical terms - how judges should deal with aggravating or mitigating factors. ${ }^{99}$ Nonetheless, guideline judgments at least provide judges with a certain sentencing framework and clarity by replacing potentially conflicting appellate decisions. ${ }^{100}$

However, guideline judgments are effectively nothing more than a special kind of appellate review that is, by its very nature, unable to produce comprehensive sentencing guidance. ${ }^{101}$ Guideline judgment mechanisms do not deal with a wide range of criminal offenses, which is why they cannot promote consistent sentencing across the board. ${ }^{102}$ Although guideline

\footnotetext{
${ }^{91}$ RaISE, supra note 9, at 8 . These guideline judgments-misleadingly denominated as "sentencing guidelines"-are available at Sentencing Guidelines for Northern Ireland, JUDICIARY NI, https://judiciaryni.uk/sentencing-guidelines-northernireland (last visited Oct. 14, 2020).

${ }^{92}$ See Appeals Against Sentence-Solemn, SCOTTISH SENTENCING COUnCIL, https://www.scottishsentencingcouncil.org.uk/ about-sentencing/guideline-judgments/appeals-against-sentence-solemn/ (last visited Oct. 14, 2020); Appeals Against Sentence-Summary, SCOTTISH SENTENCING COUNCIL, https:/www.scottishsentencingcouncil.org.uk/about-sentencing/ guideline-judgments/appeals-against-sentence-summary/ (last visited Oct. 14, 2020).

${ }^{93}$ See Division 4 Sentencing Guidelines, NSW GOVERNMENT, https://www.legislation.nsw.gov.au/view/html/inforce/current/ act-1999-092\#pt.3-div.4 (last visited Oct. 14, 2020).

${ }^{94}$ See Anderson, supra note 85, at 142, 151; Krasnostein \& Freiberg, supra note 8, at 281.

${ }^{95}$ See Sarah Krasnostein, Boulton v The Queen: The Resurrection of Guideline Judgments in Australia?, 27 CURRENT IssUES CRIM. Just. 41, 43 (2015).

${ }^{96}$ See O'Malley, supra note 89 , at 148.

${ }^{97}$ See Cyrus Tata, Sentencing and Penal Decision-Making: Is Scotland Losing its Distinctive Character?, in CRIMINAL JUSTICE In SCOTland 195, 197 (Hazel Croall, Gerry Mooney \& Mary Munro eds., 2010); RaISE, supra note 9, at 23.

${ }^{98} \mathrm{Cf}$. the following scholars who have expressed this expectation: Anderson, supra note 85, at 151; Krasnostein, supra note 95, at 53; Brown, supra note 83, at 65.

${ }^{99}$ See KeAting ET AL., supra note 89 , at 70.

${ }^{100}$ See Ashworth, supra note 90, at 521.

${ }^{101} \mathrm{Cf}$. Tom O'Malley, Living Without Guidelines, in SENTENCING GuIdeLINEs: ExPLORING THE English Model, supra note 90, at 218, 234.

${ }^{102}$ See Anderson, supra note 85, at 152.
} 
judgments may improve consistency for certain offenses, they are not the mechanism of choice in curing wide-ranging disparities within a reasonable period of time.

\section{Formal Sentencing Guidelines-Worth the Effort?}

Sentencing guidelines are another mechanism that provides sentencing guidance. The term "sentencing guidelines" typically refers to a set of prescriptive rules or standards that structure judicial discretion in order to predetermine an offender's punishment to some degree. ${ }^{103}$ Unlike guideline judgments, sentencing guidelines are created by a specialized commission, such as the U.S. Sentencing Commission or the Sentencing Council for England and Wales, and they are usually promulgated in a formalized way. Consequently, the creation of sentencing guidelines involves a considerable effort by the legislature to set the normative framework and the guidelines establishing body. Therefore, the following section will assess whether sentencing guidelines are worth the effort. In this regard, this Article will undertake a detailed assessment of sentencing guidelines and explore the various sentencing guidelines mechanisms that have been established in the U.S. and the U.K.

\section{Background and Aims of Sentencing Guidelines}

In 1984, the Sentencing Reform Act (SRA) laid the basis for what would become the most wellknown - and most contentious_-mechanism of sentencing guidance, namely the U.S. Federal Sentencing Guidelines. ${ }^{104}$ These federal guidelines, promulgated for the first time in 1987 and subject to multiple updates since then, were a response to growing prison populations and widespread disparities that existed in the U.S. due to virtually unlimited judicial discretion. ${ }^{105}$ Today, many U.S. jurisdictions like Minnesota, Washington, North Carolina, Oregon, Pennsylvania, and Ohio have implemented sentencing guidelines in order to resolve similar criminal justice policy issues. ${ }^{106}$

In England and Wales, a mechanism of formal sentencing guidelines was established following the Criminal Justice Act of 2003, which had led to the creation of the Sentencing Guidelines Council (SGC). ${ }^{107}$ The SGC was tasked with promulgating sentencing guidelines in order to achieve greater consistency and worked with the Sentencing Advisory Panel (SAP) - a body that advised the English Court of Appeal. ${ }^{108}$ However, this mechanism was not able to cope with rising prison populations, which the Carter Review ${ }^{109}$ identified as an issue in 2007. ${ }^{110}$ The legislature responded to this issue with the Coroners and Justice Act of 2009. This legislation replaced the SGC and the SAP with the Sentencing Council for England and Wales, and it created the framework for the English Sentencing Guidelines as they operate today. ${ }^{111}$

Sentencing guidelines mechanisms have also been introduced throughout the U.K. In Scotland, the Criminal Justice and Licensing (Scotland) Act of 2010 created the Scottish Sentencing Council

\footnotetext{
${ }^{103}$ See Tom O'Malley, supra note 101, at 219; see also R. A. Duff, Guidance and Guidelines, 105 COLUM. L. REv. 1162,1164 (2005) ("A piece of authoritative advice issued to sentencers at large about how they should go about deciding the sentences they are to impose.").

${ }^{104}$ See Jeff Papa \& Chris Kashman, An Introduction to the Federal Sentencing Guidelines, 51 IND. L. REV. 357 (2018).

${ }^{105}$ See Tom O’MAlley, Sentencing Law And Practice paras. 1-11 (2016); RaISE, supra note 9, at 28; Keating ET AL., supra note 89, at 64. For details on federal sentencing before the guidelines, see Frank O. Bowman, The Failure of the Federal Sentencing Guidelines: A Structural Analysis, 105 Colum. L. Rev. 1315, 1321 (2005).

${ }^{106}$ For an overview, see Richard Frase, Sentencing Guidelines in Minnesota, Other States, and the Federal Courts: A TwentyYear Retrospective, 12 FED. SENT'G REP. 69, 70 (1999).

${ }^{107}$ See Ashworth \& Roberts, supra note 90, at 5.

${ }^{108} I d$.

${ }^{109}$ Lord Carter of Coles, Securing the Future: Proposals for the EfFicient and Sustainable Use Of Custody in ENGLAND AND WALES (2007), http://news.bbc.co.uk/2/shared/bsp/hi/pdfs/05_12_07_prisons.pdf.

${ }^{110}$ See Julian V. Roberts, Sentencing Guidelines and Judicial Discretion: Evolution of the Duty of Courts to Comply in England and Wales, 51 Brit. J. Criminology 997, 998(2011); O’Malley, supra note 105, at paras. 1-14.

${ }^{111} \mathrm{Cf}$. Coroners and Justice Act 2009, art. 118 (Eng.). For further details in this regard, see Andrew Ashworth, Coroners and Justice Act 2009: Sentencing Guidelines and the Sentencing Council, 5 CRIM. L. REV. 389 (2010).
} 
—a body tasked with establishing sentencing guidelines. ${ }^{112}$ Likewise, Northern Ireland has adopted a sentencing guidelines mechanism for the Magistrates' Courts. ${ }^{113}$ However, the Northern Irish guidelines are not established by a sentencing council; rather, they are created by the Lord Chief Justice's Sentencing Group. ${ }^{114}$

Despite their differences, these mechanisms all seek to achieve multiple goals, such as reducing crime and increasing public confidence in the criminal justice system. ${ }^{115}$ Although the precise purposes of sentencing guidelines vary from jurisdiction to jurisdiction, they all share the common goal of making sentencing more predictable and more consistent. ${ }^{116}$ In Minnesota, this ambition is even expressly laid down in Section 1A of the Minnesota Sentencing Guidelines, which states that the purpose of the Minnesota guidelines is to "establish rational and consistent sentencing standards that promote public safety, reduce sentencing disparity, and ensure that the sanctions imposed for felony convictions are proportional to the severity of the conviction offense and the offender's criminal history." 117

\section{The Structure of Sentencing Guidelines}

The most significant difference between the U.S. and the U.K. sentencing guidelines is their structure. While the U.S. has opted for a grid-based system, the U.K. jurisdictions employ a far less rigid, narrative-based system of sentencing guidelines.

\subsection{Grid-Based Sentencing Guidelines in the US}

Under the U.S. Federal Sentencing Guidelines-distinct and yet similar to the guidelines in many states in the U.S.- - sentencing is structured as follows: Using a guidelines manual, the judge must determine two scores, namely the offense level and the criminal history score. ${ }^{118}$ The "offense level" is composed of the "base offense level"-depending on the offense of which the defendant was convicted - and subsequent upwards or downwards adjustments—depending on several specific offense characteristics. Aggravated assault, for example, has a "base offense level" of 14; if the offense was motivated by a payment, a score of 2 would be added; if the victim sustained bodily injury, a score of 3 would be added; if a firearm was discharged, another 5 would be added. ${ }^{119}$ Having calculated the overall "offense level" and the offender's "criminal history score", the judge must then consult a two-dimensional grid, the U.S. Federal Sentencing Table. This table measures the seriousness of the offense on its vertical axis-ranging from 1 to 43 - whereas the offender's criminal history is measured along its horizontal axis - on a scale from I to VI. ${ }^{120}$

This brief overview already reveals the main problem of the U.S. Federal Sentencing Guidelines: A guidelines manual that encompasses more than 600 pages and a sentencing table that sets out

\footnotetext{
${ }^{112}$ See Neil Hutton \& Cyrus Tata, A Sentencing Exception? Changing Sentencing Policy in Scotland, 22 FED. SENT'G REP. 272, 276 (2010).

${ }^{113}$ See Sentencing Guidelines-Magistrates' Court, JUDICIARY NI, https://judiciaryni.uk/sentencing-guidelines-magistratescourt (last visited Oct. 14, 2020).

${ }^{114}$ RaISE, supra note 9, at 7.

${ }^{115}$ See Dhami et al., supra note 83 , at 240 .

${ }^{116}$ See also Duff, supra note 103, at 1166.

${ }^{117}$ Minn. Sent'g Guidelines and Commentary \& 1A (Minn. Sent'G Comm'N, 2020) https://mn.gov/msgc-stat/ documents/Guidelines/2020/August2020MinnSentencingGuidelinesCommentary.pdf.

${ }^{118}$ For further details, see Bowman, supra note 105, at 1324; Michael Tonry, SEntencing Fragments: Penal Reform in AMERICA, 1975-2025, 130 (2016); see also Andreas von Hirsch, Guidance by Numbers or Words? Numerical versus Narrative Guidelines for Sentencing, in Sentencing Reform: Guidance or Guidelines? 46 (Ken Pease \& Martin Wasik eds., 1987).

${ }^{119}$ See U.S. Sent'G GUidelines MANUAL $\$ 2$ A2.2 (U.S. SENT’G COMM’N, 2018) https://www.ussc.gov/sites/default/files/pdf/ guidelines-manual/2018/GLMFull.pdf.

${ }^{120} \mathrm{Id}$. at 407 .
} 
more than 250 possible sentencing ranges is way too complex. ${ }^{121}$ The guidelines have introduced an extremely bureaucratic and mechanical approach to sentencing, ${ }^{122}$ their application results in foreseeably high error rates, ${ }^{123}$ and appellate review has become an exercise in "checking the district court's math." 124

Although it is possible to remedy at least some of these flaws by implementing an electronic guidelines calculator tool like Maryland's, ${ }^{125}$ or by using a far less detailed sentencing table like Minnesota's, which only has 11 severity levels, ${ }^{126}$ a general problem with grid-based sentencing guidelines remains: They cannot deal with factors that are only of relevance in a particular case. ${ }^{127}$ In other words, grid-based sentencing guidelines are unable to capture relevant differences between individual cases, which means that they impede individualized justice to some extent. ${ }^{128}$ Yet, it is the very aim of the U.S. sentencing guidelines, at both the state and federal levels, to produce uniformity in sentencing and promote consistent outcomes. ${ }^{129}$ Moreover, two-dimensional grids are the logical consequence of a "just deserts" rationale, which implies that two offenders who commit the same offense and have similar criminal records "deserve" the same criminal punishment. ${ }^{130}$

It is also noteworthy that the U.S. Federal Sentencing Guidelines provide some flexibility because they are no longer mandatory. Rather, in 2005, the U.S. Supreme Court judgment in Booker ${ }^{131}$ rendered the Guidelines advisory. ${ }^{132}$ This means that the Guidelines only serve as "the starting point and the initial benchmark" for a judge's determination of a federal sentence. ${ }^{133}$ Moreover, as Booker also introduced a new standard of judicial review, the U.S. Federal Sentencing Guidelines are now only relevant in determining the "reasonableness" of a federal sentence. ${ }^{134}$ Similarly, the sentencing guidelines used in many U.S. jurisdictions, like Washington and Minnesota, are presumptive in nature - which means that judges may impose a sentence outside the guideline-range as long as they explain why the case before them is not a typical one. ${ }^{135}$

\subsection{Narrative-Based Sentencing Guidelines in the U.K.}

A different system of sentencing guidelines operates in the three U.K. jurisdictions. One of them are the Sentencing Guidelines for England and Wales. Their characteristic feature is that they follow a "narrative" (or "discursive") approach—which means that the guidelines set out a series

\footnotetext{
${ }^{121}$ From the vast literature on the U.S. Federal Sentencing Guidelines, see Dawinder Sidhu, Towards the Second Founding of Federal Sentencing, 77 MD. L. REV. 485, 495 (2018); Bowman, supra note 105, at 1347; ToNRY, supra note 118, at 98 ("[O]ne of the commission's worst blunders was the promulgation of the forty-three-level sentencing grid.").

${ }^{122}$ See Maimon Schwarzschild, The Bureaucratic Takeover of Criminal Sentencing, 49 N.M. L. REV. 93 (2019); see also TONRY, supra note 118, at 147 (stating that the guidelines are a "sentencing machine").

${ }^{123}$ See Michael Tonry, Sentencing Matters 98 (1996).

${ }^{124}$ Sidhu, supra note 121, at 487; Carter Gee-Taylor, Deference Errors: The United States Sentencing Guidelines, Chevron, and the Appellate Presumption of Reasonableness, 89 U. Colo. L. Rev. 1209, 1213 (2018).

${ }^{125}$ See Danielle P. Fox et. al, Improving Judicial Administration Through Implementation of an Automated Sentencing Guidelines System, 29 CRIM. Just. POL’y ReV. 489 (2018).

${ }^{126}$ See Minn. Sent'g Guidelines Grid (Minn. SEnT'G Comm'n, 2019), http://mn.gov/msgc-stat/documents/Guidelines/ 2019/StandardGrid.pdf.

${ }^{127}$ See TONRY, supra note 123 , at 22.

${ }^{128}$ See Duff, supra note 103 , at 1173 .

${ }^{129} \mathrm{Cf}$. Duff, supra note 103 , at 1172 .

${ }^{130} \mathrm{Cf}$. TONRY, supra note 123, at 19; see also Michael J. Allen, Sentencing Guidelines: Lessons to be Learned?, 39 N. IR. LEGAL Q. 315, 320 (1988).

${ }^{131}$ United States v. Booker, 543 U.S. 20 (2005).

${ }^{132}$ See Kevin R. Reitz, The Enforceability of Sentencing Guidelines, 58 STAN. L. REv. 155 (2005); Frank O. Bowman, The Year of Jubilee ... or Maybe Not: Some Preliminary Observations About the Operation of the Federal Sentencing System After Booker, 43 Hous. L. Rev. 279 (2006); Nancy Gertner, From Omnipotence to Impotence: American Judges and Sentencing, 4 OHIO ST. J. CRIM. L. 523, 536 (2007).

${ }^{133}$ See Sidhu, supra note 121, at 492; Papa \& Kashman, supra note 104, at 365; Gee-Taylor, supra note 124, at 1213.

${ }^{134}$ See Papa \& Kashman, supra note 104, at 365; Carter Gee-Taylor, supra note 124, at 1224.

${ }^{135}$ See TONRY, supra note 118 , at 33.
} 
of reasoning steps that judges are to follow when they determine a criminal sentence. ${ }^{136}$ Unlike the U.S., England and Wales have not implemented a comprehensive manual of sentencing guidelines; rather, England and Wales have created separate guidelines for particular offenses, or groups of offenses, which are available at the Sentencing Council's website. ${ }^{137}$

The Scottish Sentencing Guidelines are very similar to the English model. ${ }^{138}$ However, only the sentencing guideline on "principles and purposes of sentencing" has been approved so far. ${ }^{139}$ Apart from that, only five other sentencing guidelines are in progress at the moment. ${ }^{140}$ This illustrates that the actual development of sentencing guidelines in Scotland has only just begun, even though the legal framework for the Scottish Sentencing Guidelines was created ten years ago.

Northern Ireland, however, has already established a far broader set of sentencing guidelines applicable in the Magistrates' Courts. ${ }^{141}$ Although these guidelines seem to resemble the U.S. guidelines as they employ a grid format, the Northern Irish Magistrates' Court Sentencing Guidelines are, in fact, narrative-based because they only indicate starting points and sentencing ranges for particular kinds of offenses. In addition, the guidelines include a list of relevant case law, as well as examples of possible mitigating and aggravating factors. Overall, they guide judges in their decisions, but they do not set out a series of reasoning steps like the guidelines in England and Wales.

Compared to the U.S. Federal Sentencing Guidelines, the U.K. guidelines are less rigid in terms of their structure, but effectively more binding in nature. For example, the Scottish courts of first instance and appeal "must have regard" to any applicable guideline. ${ }^{142}$ Similarly, the courts in England and Wales "must follow" the guidelines. ${ }^{143}$ However, the U.K. guidelines provide some leeway in order to cater for exceptional cases. The English courts may depart from the guidelines if they are satisfied that following the guidelines "would be contrary to the interests of justice"144, and the Scottish courts may decide to apply an exception clause, if it is provided for in a guideline, or simply not follow the guidelines as long as they state the reasons for this decision. ${ }^{145}$

Overall, narrative-based guidelines allow for the application of judicial experience and expertise. ${ }^{146}$ They also represent a nuanced approach because they structure judicial discretion and retain sufficient flexibility at the same time. ${ }^{147}$ Moreover, narrative-based sentencing guidelines focus on consistency of approach-which, in turn, increases the likelihood of more consistent sentencing outcomes. ${ }^{148}$

\footnotetext{
${ }^{136}$ See Dhami et. al., supra note 83 , at 243; RaISE, supra note 9 , at 9.

${ }^{137}$ See Ashworth \& Roberts, supra note 90, at 6; see also SENTENCING CounCIL For ENGLAND AND WaLEs, https://www. sentencingcouncil.org.uk/ (last visited Oct. 14, 2020).

${ }^{138} \mathrm{Cf}$. Criminal Justice and Licensing (Scotland) Act 2010, (ASP 13) $₫ 3(3)-(4)$ (stating that the Scottish Sentencing Guidelines may relate to "the principles and purposes of sentencing, sentencing levels, the particular types of sentence that are appropriate for particular types of offence or offender ... the guidelines may be general in nature or relate to a particular category of offence or offender or a particular matter relating to sentencing.").

${ }^{139}$ See Scottish Sent'g Council, Principles and Purposes of Sentencing (Nov. 26, 2018), https://www. scottishsentencingcouncil.org.uk/media/1964/guideline-principles-and-purposes-of-sentencing.pdf.

${ }^{140}$ These guidelines concern the "sentencing process," "sentencing of young people," "death by driving," "sexual offences," and "environmental and wildlife crime"; see Guidelines in Development, SCOTTISH SENT'G CounCIL (2019), https://www. scottishsentencingcouncil.org.uk/sentencing-guidelines/guidelines-in-development/.

${ }^{141}$ See Sentencing Guidelines - Magistrates' Court, JUDICIARY N. IR., https://judiciaryni.uk/sentencing-guidelines-magistrates-court.

${ }^{142}$ Criminal Justice and Licensing (Scotland) Act 2010, (ASP 13) $\$ 6(1)$.

${ }^{143}$ Coroners and Justice Act 2009, c. $1, \S 125(1)$ (a) (Eng.). This wording is even meant to be more binding than "must have regard" which was the term used in Criminal Justice Act 2003, c. 1. \$\$ 172(1), 174(2) (Eng.). For details in this respect, see Julian V. Roberts, Structured Sentencing: Lessons from England and Wales for Common Law Jurisdictions, 14 PUNISHMENT \& Soc'y 267, 273 (2012).

${ }^{144}$ Coroners and Justice Act 2009, c. 1, \$ 125(1)(b) (Eng.).

${ }^{145} \mathrm{Cf}$. Criminal Justice and Licensing (Scotland) Act 2010, (ASP 13) $\$ 6(2)$.

${ }^{146}$ See Dhami, supra note 83 , at 243.

${ }^{147} I d$.

${ }^{148}$ See Duff, supra note 103, at 1188; Briana L. Rosenbaum, Sentence Appeals in England: Promoting Consistent Sentencing Through Robust Appellate Review, 14 J. App. Prac. \& Process 81, 122 (2013); Rob Allen, The Sentencing Council for
} 


\section{The Role of Sentencing Commissions and Councils}

In drafting, refining, and adapting the guidelines, sentencing commissions and councils play a central role. In the U.S., the Federal Sentencing Guidelines are created by the U.S. Sentencing Commission, an independent body that is part of the judicial branch. ${ }^{149}$ Inter alia, the Commission's task is to establish sentencing policies for the federal criminal justice system. ${ }^{150}$ Most importantly, the U.S. Federal Sentencing Commission monitors and adjusts the guidelines. ${ }^{151}$ In the U.K., the Sentencing Council for England and Wales, the Scottish Sentencing Council, and the Lord Chief Justice's Sentencing Group fulfill a similar role. ${ }^{152}$

Unlike the legislature, these specialized bodies have the time and expertise to create meaningful sentencing guidelines, ${ }^{153}$ and when establishing sentencing guidelines, these aspects are crucial. For example, before publishing a definitive guideline, the Sentencing Council for England and Wales conducts empirical research and a lengthy public consultation, invites external experts, and produces a draft of the guideline as well as a consultation paper. ${ }^{154}$ Likewise, the creation of sentencing guidelines in Scotland involves several stages-beginning with an initial consideration of the guideline topic and a cost assessment, followed by the development of a draft guideline and various consultations - until the final guideline is eventually submitted to the High Court of Justiciary for approval. ${ }^{155}$ Once a sentencing guideline is in place, the Scottish Sentencing Council must review the guideline's implementation on a regular basis. ${ }^{156}$

With regard to the composition of sentencing commissions and councils, it can be noted that many of these bodies have at least one member that is a representative of victim support agencies. ${ }^{157}$ These members are in a position to make a valuable contribution in terms of public views on sentencing and victims' expectations towards criminal justice. ${ }^{158}$ The necessary legal expertise is catered for by the other members of sentencing councils or commissions, who are typically former or serving judges, as well as scholars whose research focuses on criminal law and criminology. ${ }^{159}$

Apart from the question of composition, past experiences with sentencing councils and commissions have shown that these bodies should be insulated from external pressures. In the U.S., for example, Congress has, on occasion, intervened in setting the guidelines-all of these interventions led to increased punishment levels without being based on empirical data. ${ }^{160}$ Thus, sentencing councils and commissions should be strictly independent in their work. This will ensure the creation of evidence-based and, thus, more legitimate sentencing guidelines.

\footnotetext{
England and Wales: Brake or ACCelerator on the Use of Prison? 15 (2016), http://www.transformjustice.org.uk/wpcontent/uploads/2016/12/TJ-DEC-8.12.16-1.pdf.

${ }^{149} 28$ U.S.C. $\$ 991(\mathrm{a})(2012)$.

${ }^{150} 28$ U.S.C. $\$ 991$ (b) (2012).

${ }^{151}$ See Gee-Taylor, supra 124, at 1248; Sidhu, supra note 121, at 492. For further details on the Commission's tasks from a historical perspective, see Brent Newton \& Dawinder Sidhu, The History of the Original United States Sentencing Commission, 1985-1987, 45 HoFstra L. REv. 1167 (2017).

${ }^{152}$ See RaISE, supra note 9, at 7, 22.

${ }^{153}$ See KeATING ET AL., supra note 89, at 66; O’Malley, supra note 101, at 232.

${ }^{154}$ See Cahillane, supra note 82, at 13; see also RaISE, supra note 9, at 15.

${ }^{155}$ See Criminal Justice and Licensing (Scotland) Act 2010, (ASP 13) $\$ \$ 3(1),(5)$.

${ }^{156}$ See Criminal Justice and Licensing (Scotland) Act 2010, (ASP 13) $\$ \$ 3(6)(a), 7,8,8 \mathrm{~A}$.

${ }^{157}$ See Ian Edwards, Sentencing Councils and Victims, 75 MoD. L. REv. 324, 331 (2012).

${ }^{158}$ See Id.; see also Mike Hough \& Amy Kirby, The Role of Public Opinion in Formulating Sentencing Guidelines, in SENTENCING Guidelines: EXPlORING THE ENGLish Model, supra note 90, at 140.

${ }^{159}$ For further details on the composition and the organization of the US Federal Sentencing Commission, see Who We Are, United STATES SENT'G COMM'N. (2020), https://www.ussc.gov/about/who-we-are/organization. For more information about the members of the Sentencing Council for England and Wales, see About Us, SENT'G CounCIL (2020) https://www. sentencingcouncil.org.uk/about-us/council-members/.

${ }^{160}$ See Bowman, supra note 105, at 1341; Gee-Taylor, supra note 124, at 1249.
} 


\section{Assessing the Effectiveness of Sentencing Guidelines}

Given the different structures and concepts of sentencing guidelines in the U.S. and the U.K., the question to consider is which of these models has achieved its ambitions, has increased consistency in sentencing, and has, therefore, been "effective."161

The evidence regarding the U.S. Federal Sentencing Guidelines is pretty clear: Although older studies demonstrated that the guidelines reduced inter-judge disparities within the U.S. judicial districts, ${ }^{162}$ research on federal sentencing after Booker in 2005 demonstrates that disparities have increased. ${ }^{163}$ These disparities should also give rise to concern as research has shown that the U.S. Federal Sentencing Guidelines have produced remarkable discriminatory racial and gender disparities in U.S. federal sentencing practice. ${ }^{164}$ However, research has demonstrated that these disparities are linked to a judge's political affiliation. ${ }^{165}$ Therefore, racial and gender disparities are not caused solely by the guidelines. Instead, they are also a result of the fact that judges in the U.S. are elected.

Apart from the disparity issue, the U.S. Federal Sentencing Guidelines are contentious for several other reasons: First, they have created undue severities and contributed to the phenomenon of mass incarceration in the U.S. ${ }^{166}$ Second, the guidelines have shifted discretion to public prosecutors whose sentencing power under the plea bargaining regime has increased. ${ }^{167}$ Therefore, disparities and injustices have simply shifted to another-earlier and less visible — stage of the sentencing process. ${ }^{168}$

U.S. sentencing expert Michael Tonry found that federal sentencing was less just and less fair in 2015 than in $1985 .{ }^{169} \mathrm{He}$ also noted that the Federal Sentencing Guidelines were "the most ... disliked sentencing reform initiative in the history of the US." ${ }^{170}$ In fact, research has shown that judges and prosecutors have tried to circumvent the application of the guidelines, ${ }^{171}$ illustrating that sentencing guidelines are unlikely to succeed if the judiciary does not accept them. ${ }^{172}$

\footnotetext{
${ }^{161} C f$. Nicola Padfield, Exploring the Success of Sentencing Guidelines, in SENTENCING GUIDELINES: EXPLORING THE ENGLISH MoDEL, supra note 90, at 31.

${ }^{162}$ See John M. Anderson et al., Measuring Inter-Judge Sentencing Disparity: Before and After the Federal Sentencing Guidelines, 42 J.L. \& ECON. 271, 273 (1999); Paul Hofer et al., The Effect of the Federal Sentencing Guidelines on InterJudge Sentencing Disparity, 90 J. CRIM. L. \& CRIMINOLOGY 239, 241 (1999).

${ }^{163}$ See Ryan W. Scott, Inter-Judge Sentencing Disparity after Booker: A First Look, 63 STAN. L. ReV. 1 (2010); Crystal S. Yang, Have Inter-Judge Sentencing Disparities Increased in an Advisory Guidelines Regime? Evidence from Booker, (Coase-Sandor Inst. L. \& Econ., Working Paper No. 662, 2014).

${ }^{164}$ See David B. Mustard, Racial, Ethnic, and Gender Disparities in Sentencing: Evidence from the US Federal Courts, 44 J.L. \& ECON. 285 (2001); Todd Sorensen et al., Race and Gender Differences Under Federal Sentencing Guidelines, 102 AM. ECON. ReV. 256 (2012); Joshua B. Fischman \& Max M. Schanzenbach, Racial Disparities Under the Federal Sentencing Guidelines: The Role of Judicial Discretion and Mandatory Minimums, 9 J. EMPIRICAL LEGAL STUD. 729 (2012); Crystal S. Yang, Free at Last? Judicial Discretion and Racial Disparities in Federal Sentencing, 44 J. LEGAL STUD. 75 (2015); Jeffrey T. Ward et al., Unpacking Gender and Racial/Ethnic Biases in the Federal Sentencing of Drug Offenders: A Causal Mediation Approach, 46 J. CRIM. JUST. 196 (2016).

${ }^{165}$ See Alma Cohen \& Crystal S. Yang, Judicial Politics and Sentencing Decisions, 11 AM. ECON. J. 160 (2019).

${ }^{166}$ See Bowman, supra note 105, at 1328; Gee-Taylor, supra note 124, at 1211; Sidhu, supra note 121, at 493; Paul Hofer, After Ten Years of Advisory Guidelines, and Thirty Years of Mandatory Minimums, Federal Sentencing Still Needs Reform, 47 U. Tol. L. REv. 649, 680 (2016).

${ }^{167}$ See, e.g., Albert Alschuler, The Failure of Sentencing Guidelines: A Plea for Less Aggregation, 58 U. CHI. L. REV. 901,925 (1991); William J. Stuntz, Plea Bargaining and Criminal Law's Disappearing Shadow, 117 Harv. L. Rev. 2548, 2559 (2004); Bowman, supra note 105, at 1336; TONRY, supra note 118, at 154; Stephen E. Vance \& J.C. Oleson, Displaced Discretion: The Effects of Sentencing Guidelines on Prosecutors' Charge Bargaining in the District of Columbia Superior Court, 25 CRIM. JUST. POL'Y REV. 347 (2014).

${ }^{168}$ See Keating ET AL., supra note 89, at 68; see also Ronald F. Wright, Sentencing Commissions as Provocateurs of Prosecutorial Self-Regulation, 105 ColuM. L. REV. 1010 (2005).

${ }^{169}$ TONRY, supra note 118 , at 153.

${ }^{170}$ TONRY, supra note 123 , at 72 .

${ }^{171}$ See Alschuler, supra note 167 , at 924 ; see also TONRY, supra note 118 , at 34 .

${ }^{172}$ See O'Malley, supra note 101, at 229.
} 
The presumptive sentencing guidelines at the state level in the U.S., however, have proven far more successful. According to Tonry, the states' guidelines have increased consistency and sentencing fairness. ${ }^{173}$ This result is also warranted by a very recent study that analyzed presumptive sentencing guidelines and found that they have not only led to less severe sentencing levels but also to reductions in racial and inter-judge disparities. ${ }^{174}$

Assessing the effectiveness of the various U.K. sentencing guidelines represents a more difficult endeavor. In Northern Ireland, there are no studies conducted, and in Scotland, there is only one single sentencing guideline in place. This guideline was approved in October 2018, and a report on the guideline's implementation has not yet been published.

In England and Wales, far less research has been conducted than in the U.S. on the effectiveness of sentencing guidelines. ${ }^{175}$ Nonetheless, there are at least some studies. For example, a recent study revealed that judges in England and Wales were confident in the guidelines' ability to increase consistency and found the guidelines useful. ${ }^{176}$ Moreover, there is evidence that the guidelines have not undermined individualization. ${ }^{177}$ This finding might explain why the guidelines enjoy broad acceptance among the judiciary, especially since judges in England and Wales were opposed to U.S. style guidelines from the very beginning. ${ }^{178}$

The above findings demonstrate that experiences with sentencing guidelines are mixed. The U.S. Federal Sentencing Guidelines have not achieved their ambition, whereas the presumptive sentencing guidelines at the U.S. state level have proven more successful. This illustrates that grid-based systems can work-as long as one accepts their just deserts rationale as an appropriate sentencing policy.

Narrative-based sentencing guidelines have also proven successful. They represent an alternative to the more rigid grid-based sentencing guidelines but should be accompanied by a compliance requirement to ensure consistency under a discursive framework. ${ }^{179}$ Moreover, they should be sufficiently detailed in order to provide judges with actual sentencing guidance. ${ }^{180}$

Overall, one particular element has proven essential under both models of sentencing guidelines: In order to be successful, sentencing guidelines must provide some degree of flexibility. In a discursive regime, this flexibility is inherent in the very nature of the guidelines. In a grid-based regime, flexibility may be achieved by attaching a presumptive character to the guidelines and reducing the complexity of the sentencing grid. Inflexible and too rigid sentencing guidelines are likely to be rejected by the judiciary and will, therefore, fail to achieve their ambition.

\section{Sentencing Advisory Bodies-or: the Australian Approach}

Unlike the U.S. and the U.K., Australia has not, or at least not yet, adopted sentencing guidelines. Instead, many Australian states have only created sentencing advisory bodies, representing a different and unique approach to sentencing guidance.

At present, sentencing advisory bodies operate in four Australian states-New South Wales, Victoria, Queensland, and Tasmania. ${ }^{181}$ What distinguishes these institutions from the U.S.

\footnotetext{
${ }^{173}$ See TONRY, supra note 118 , at 33.

${ }^{174}$ See Griffin Edwards et al., The Effects of Voluntary and Presumptive Sentencing Guidelines, 98 TEX. L. REV. 1 (2019).

${ }^{175}$ See Julian V. Roberts, Structuring Sentencing in Canada, England and Wales: A Tale of Two Jurisdictions, 23 CRIM. L.F. 319, 339 (2012).

${ }^{176}$ See Mandeep K. Dhami, Sentencing Guidelines in England and Wales: Missed Opportunities?, 76 L. \& CONTEMP. ProbS. 289, 302 (2013).

${ }^{177}$ See Julian V. Roberts, et al., Individualisation at Sentencing: The Effects of Guidelines and "Preferred" Numbers, 2 CRIM. L. REV. 123 (2018).

${ }^{178} \mathrm{Cf}$. Dhami et al., supra note 83, at 243 .

${ }^{179}$ See Roberts, supra note 175 , at 340.

${ }^{180} \mathrm{Id}$. at 339.

${ }^{181}$ These bodies are: The New South Wales Sentencing Council, http://www.sentencingcouncil.justice.nsw.gov.au/; the Victoria Sentencing Advisory Council, https://www.sentencingcouncil.vic.gov.au/; the Queensland Sentencing Advisory
} 
Federal Sentencing Commission, or the Sentencing Council for England and Wales, is that the Australian sentencing advisory bodies do not establish formal sentencing guidelines. Rather, they primarily focus on research and education about sentencing. For example, the Queensland Sentencing Advisory Council operates under the "Inform-Engage-Advise" policy. ${ }^{182}$ They also publish teaching materials for high school and university education and run the "Judge for Yourself" program which is aimed at increasing public confidence in the judiciary and the sentencing process. ${ }^{183}$ The Victoria Sentencing Advisory Council runs a similar program, called "You be the Judge." 184

This raises the question of why Australia has rejected formal sentencing guidelines so far. The answer to this question has to do with the fact that Australia places great emphasis on individualized justice and judicial discretion. ${ }^{185}$ Consequently, the Australian model of sentencing follows an approach that has become known as "instinctive synthesis" which requires judges to "measure" all available evidence in determining a criminal sentence. ${ }^{186}$ In Markarian v. The Queen, Judges Kirby and McHugh have described the procedure under "instinctive synthesis" as follows: "[T]he judge identifies all the factors that are relevant to the sentence, discusses their significance, and then makes a value judgment as to what is the appropriate sentence given all the factors of the case." 187 Thus, "instinctive synthesis" largely relies on a judge's personal expertise and his individual value judgment.

However, Australia is not entirely opposed to sentencing guidelines, as is apparent from sentencing guidelines endeavors in the state Victoria. ${ }^{188}$ Thus, the creation of a sentencing advisory body may represent a first step towards structuring judicial discretion. A sentencing advisory body may conduct initial research on sentencing patterns and collect data-evidence that can later form the basis for the creation of sentencing guidelines.

In this respect, it should be noted that such endeavors require substantive political will and support. This was the experience made in Australia's neighbor jurisdiction, New Zealand, where the legislator passed the Sentencing Council Act 2007, ${ }^{189}$ but actual implementation never took place. This was partly the result of a change in political leadership. In November 2008, New Zealand elected a new government that soon announced it would neither make any appointments to the sentencing council nor proceed with the sentencing guidelines project. ${ }^{190}$ Since then, not

\footnotetext{
Council, https://www.sentencingcouncil.qld.gov.au/; and the Tasmanian Sentencing Advisory Council, https://www. sentencingcouncil.tas.gov.au/. The Sentencing Advisory Council of South Australia, however, has ceased its operations, see Sentencing Advisory Council of South Australia, Governmnent OF SOURTH Australia, https://www.agd.sa.gov.au/ about-us/boards-and-committees/sentencing-advisory-council-sa.

${ }^{182}$ See About Us, QueEnSLAND SENT'G ADVISORY COUnCIL (2020), https://www.sentencingcouncil.qld.gov.au/about-us.

${ }^{183}$ See Education \& Resources, QUEENSLAND SENT'G ADVISORY COUNCIL (2020), https://www.sentencingcouncil.qld.gov.au/ education-and-resources.

${ }^{184}$ See Education, Victoria SENT'G AdVISORY COUNCIL (2020), https://www.sentencingcouncil.vic.gov.au/education.

${ }^{185} \mathrm{Cf}$. Arie Freiberg, Australia: Exercising Discretion in Sentencing Policy and Practice, 22 FED. SenT'G ReP. 204 (2010).

${ }^{186}$ See Dhami et al., supra note 83, at 241; RaISE, supra note 9, at 8. For further details, see Terry Hewton, Instinctive Synthesis, Structured Reasoning, and Punishment Guidelines: Judicial Discretion in the Modern Sentencing Process, 31 AdEL. L. Rev. 79 (2010).

${ }^{187}$ Markarian v The Queen (2005) 228 CLR 357 (Austl.).

188 See Victoria Sent'g Advisory Council, A Sentencing Guidelines Council FOr Victoria: Report 31, 43, 55 (2018), https://www.sentencingcouncil.vic.gov.au/sites/default/files/2019-08/A_Sentencing_Guidelines_Council_for_Victoria_Report.pdf.

${ }^{189}$ For details on the background of the Sentencing Council Act 2007, see LAW Comm'N, SENTENCING GuIDELINES AND PAROLE REFORM (R94) (Aug. 2006), 10, 17, https://www.lawcom.govt.nz/sites/default/files/projectAvailableFormats/NZLC\% 20R94.pdf (PDF).

${ }^{190}$ Warren Young \& Andrea King, Sentencing Practice and Guidance in New Zealand, 22 Fed. SENT'G ReP. 254, 260 (2010); for further details on the New Zealand sentencing guidelines project, see Sean J. Mallett, Judicial Discretion in Sentencing: A Justice System That Is No Longer Just?, 46 VictoRIA U. WeLL. L. ReV. 533, 553 (2015).
} 
much has changed-and in June 2017, New Zealand even repealed the Sentencing Council Act 2007 in order to clarify that a sentencing council would not be created. ${ }^{191}$

\section{Conclusion}

The comparative analysis of sentencing guidance mechanisms in the U.S., the U.K., and Australia has revealed that guideline judgments are only of limited value. Given their narrow scope, they cannot achieve consistency for a wide range of offenses or cases. Formal sentencing guidelines, however, are far more suitable in this regard. Nonetheless, the different experiences of the U.S. and the U.K. have shown that sentencing guidelines must provide sufficient flexibility in order to be successful. Overly rigid mechanisms, like the U.S. Federal Sentencing Guidelines, are likely to face broad opposition from the judiciary and will therefore fail to achieve their ambition. Narrative-based sentencing guidelines, like the ones operating in England and Wales, avoid the pitfalls of the U.S. Federal Sentencing Table. Moreover, they are based on a different rationale which implies that narrative-based sentencing guidelines may represent a particularly useful model for jurisdictions opposed to a "just deserts" rationale.

Apart from that, this Article has noted that sentencing councils and commissions, with an independent status, are extremely useful institutions in striving for greater consistency. Likewise, the Australian experience has shown that sentencing advisory bodies may fulfill a similar role in jurisdictions that are - at least prima facie-opposed to formal sentencing guidelines. The Australian experience has also revealed that the creation of a sentencing advisory body may represent the first step within a broader, more comprehensive criminal justice reform that ultimately aims to establish sentencing guidelines. In this regard, securing the necessary political support will be crucial.

\section{The Way Ahead: How to Improve Consistency in German Sentencing Practice}

Having explored disparities in German sentencing practice as a phenomenon, and having looked at how foreign jurisdictions have responded to similar issues in their sentencing practices, the last section of this Article will present three steps which German criminal justice reform should follow in striving for greater consistency: First, Germany should remedy the flaws of the current sentencing framework; second, Germany should remedy the lack of sentencing data; and third, Germany should implement a flexible sentencing guidelines regime.

\section{Remedying the Flaws of the Current Sentencing Framework}

As this Article has demonstrated, wide statutory sentencing ranges are one of the main reasons for the observed disparities in German sentencing practice. ${ }^{192}$ Moreover, these broad statutory sentencing ranges confront judges with the almost impossible task of reasoning, for example, why a sentence of three years and two months of imprisonment and not a sentence of three years and eight months is the appropriate sanction in a particular case. Given these difficulties, a reform should limit the existing overly broad statutory sentencing ranges—a suggestion that has already been made by several German scholars. ${ }^{193}$

In addition, a reform should remedy the current flaws of Section $46 \mathrm{StGB} .{ }^{194}$ In particular, the vague provision in Section 46(1) StGB on principles and purposes of criminal punishment needs

\footnotetext{
${ }^{191}$ See Statutes Repeal Bill Exposure Draft-Explanatory Material, PARLIAMENTARY Couns. OfF., http://www.pco.govt.nz/ srb-explanatory-material.

${ }^{192}$ See infra subsection $\mathrm{B}(\mathrm{II})(1)$.

${ }^{193}$ See Streng, supra note 7, at 594; KASPAR, supra note 24, at 107; Verrel, supra note 24, at 813.

${ }^{194}$ For details on Section 46 StGB, see infra subsection B(II)(2.1).
} 
clarification because a fundamental question like this should not be influenced by individual, and disparate, views of criminal judges. ${ }^{195}$ In this regard, Kaspar has made a detailed suggestion on what a revised Section 46 StGB could look like. ${ }^{196}$ His suggestion represents a good basis for further discussion-although one should consider adding an express clause on consistency to his proposal in order to finally recognize consistency as a sentencing value.

\section{Remedying the Lack of Sentencing Data}

The second step of reform concerns the fact that German judges experience severe difficulties in researching how other judges have decided similar cases - at present, local justice culture essentially serves as the only guidance. ${ }^{197}$ In remedying this issue, this Article suggests three approaches: First, Germany should create a sentencing information system. Second, Germany should establish a sentencing advisory body. Third, Germany should implement a formal, but flexible, sentencing guideline regime.

\section{Creating a Sentencing Information System}

Over the last couple of years, a significant number of sentencing experts have claimed that Germany should implement a sentencing information system. ${ }^{198}$ The advantage of having a specific sentencing database is that it increases transparency and makes sentencing patterns more accessible to judges. ${ }^{199}$ Thus, a database would help judges in searching for and finding similar cases. Using a keyword search, judges could indicate which aggravating and mitigating factors they consider relevant in a particular case, and the sentencing information system would direct them to court decisions in similar, previous cases. ${ }^{200}$

Interestingly, Germany is far behind other jurisdictions in this regard. For example, Scotland created the prototype for its current database almost two decades ago. ${ }^{201}$ In the Republic of Ireland, the Irish Sentencing Information System ("ISIS") provides data on the Irish sentencing practice. $^{202}$ Likewise, New South Wales has implemented the Judicial Information Research System ("JIRS"), which allows for a precise analysis of previous cases in relation to factors such as age and prior convictions. ${ }^{203}$

A particularly interesting example is Japan, where the Supreme Court initiated a sentencing database in May 2008 to provide both lay judges and professional judges with information on sentencing patterns. ${ }^{204}$ Within a relatively short period of time, information on more than 3,000 cases was added to the system, and judges soon expressed that they considered the database a great help in sentencing new cases. ${ }^{205}$

\footnotetext{
${ }^{195}$ See also Streng, supra note 7 , at 595 ; Verrel, supra note 24 , at 812.

${ }^{196}$ KASPAR, supra note 24 , at 104 .

${ }^{197} \mathrm{Cf}$. infra subsection $\mathrm{B}(\mathrm{II})(3)$.

${ }^{198}$ See Julia Heinrich, Die GesetZliche Bestimmung von STRAFschärfungen, 122 (2016); Frisch, supra note 21, at 465; KASPAR, supra note 24, at 115; Streng, supra note 7, at 599.

${ }^{199}$ See Streng, supra note 7, at 599; see also Marc L. Miller, A Map of Sentencing and a Compass for Judges: Sentencing Information Systems, Transparency, and the Next Generation of Reform, 105 Colum. L. Rev. 1351, 1374 (2005).

${ }^{200}$ See Frisch, supra note 21, at 466.

${ }^{201}$ See Cyrus Tata et al., A Sentencing Information System For The High Court Of Justiciary Of Scotland 17, 50, 75 (2002); Tata, supra note 97 at 210.

${ }^{202}$ See Brian Conroy \& Paul Gunning, The Irish Sentencing Information System (ISIS): A Practical Guide to a Practical Tool, 1 Jud. Stud. Inst. J. 37 (2009).

${ }^{203}$ Krasnostein \& Freiberg, supra note 8, at 278.

${ }^{204}$ See Yuji Shiroshita, Current Trends and Issues in Japanese Sentencing, 22 FED. SENT'G REP. 243, 246 (2010).

${ }^{205}$ See Frisch, supra note 21, at 466.
} 
One might criticize that a sentencing database does not necessarily lead to greater consistency, given its merely informative nature. ${ }^{206}$ However, the Japanese experience has shown that the documentation of sentencing patterns decreases the number of judgments that are either extremely mild or extremely severe. ${ }^{207}$ Moreover, a sentencing database reduces the risk of missing knowledge. ${ }^{208}$ Consequently, the data of a sentencing information system might also be useful for the work of the appellate courts, which, in turn, is likely to reduce disparities in sentencing practice overall. $^{209}$

Of course, the creation and maintenance of a sentencing information system will require financial resources. ${ }^{210}$ However, the experiences made so far have shown that the costs are reasonable. $^{211}$ Therefore, the creation of a sentencing database is not a mere matter of costs; rather, the success of a sentencing information system will depend on the willingness of judges to use $\mathrm{it}^{212}$ —an issue that could be remedied by involving judges in the creation of the database from an early stage. ${ }^{213}$ Apart from that, a sentencing information system will only serve its purpose if it includes a sufficient amount of detail, if it is equipped with a sufficient number of categories on offenses and offenders, and if it receives constant updates-ideally on a day-to-day basis. ${ }^{214}$

\section{Establishing a Sentencing Advisory Body}

In addition to the creation of a sentencing information system, Germany should establish a sentencing advisory body. In his expert opinion on German sentencing reform, Kaspar has also made this suggestion. ${ }^{215}$ However, the participants of the seventy-second Conference of the Association of German Jurists rejected this suggestion at the final vote with a notable majority of 46 to $16 .^{216}$ Regarding the experiences made abroad-especially in Australia, but also in the U.S. and the U.K.- - and the general advantages of having an expert body on sentencing in place, ${ }^{217}$ the conference result is deplorable. This Article has clearly shown that the Australian sentencing advisory bodies, as well as the various existing sentencing councils and commissions, play a crucial role in collecting and evaluating empirical data.

In Germany, the institutionalized collection and evaluation of sentencing data are even more important as this data is not publicly available. Specifically, the German Police Statistics (Polizeiliche Kriminalstatistik) ${ }^{218}$ does not include much data on sentencing practice. Moreover, the annual statistics on German criminal justice, published by the German Federal Statistics Office (Statistisches Bundesamt), ${ }^{219}$ does not include a lot of information on sentencing patterns either. Moreover, the data on sentencing stored in the German Federal Central Register is not available for the general public. Therefore, an independent sentencing advisory body could

\footnotetext{
${ }^{206} C f$. TATA ET AL., supra note 201, at 5.

${ }^{207}$ See Frisch, supra note 21, at 468.

${ }^{208} \mathrm{Id}$. at 467.

${ }^{209}$ See Streng, supra note 7, at 600.

${ }^{210}$ See Miller, supra note 199 , at 1380.

${ }^{211} I d$. at 1383; see also Frisch, supra note 21, at 467.

${ }^{212}$ See Frisch, supra note 21, at 469.

${ }^{213}$ See Miller, supra note 199 , at 1384.

${ }^{214}$ See also O'Malley, supra note 89 , at 150; Miller, supra note 199 , at 1371.

${ }^{215}$ KASPAR, supra note 24 , at 113.

${ }^{216}$ See II/2 StÄndige Deputation des Deutschen Juristentages, Verhandlungen Des 72 . Deutschen JuRistentages LEIPZIG 2018, at M 189, M 190 (2019).

${ }^{217}$ See infra subsections C(II)(3) and C(III).

${ }^{218}$ See Polizeiliche Kriminalstatistik (PKS), BUNDESKRIMINALAMT (2020), https://www.bka.de/DE/AktuelleInformationen/ StatistikenLagebilder/PolizeilicheKriminalstatistik/pks_node.htm.

${ }^{219}$ See Justiz und Rechtspflege, STATISTISCHES BUNDESAMT (2020), https://www.destatis.de/DE/Themen/Staat/JustizRechtspflege/_inhalt.html.
} 
systematically evaluate sentencing data and have a preparatory function in what should follow as step three: The implementation of formal, but flexible, sentencing guidelines.

\section{Implementing a Flexible Sentencing Guidelines Regime}

The comparative assessment of sentencing guidelines mechanisms in the U.K. and the U.S. has shown that sentencing guidelines represent a useful tool in striving for greater consistency-as long as they are combined with sufficient flexibility. ${ }^{20}$ Interestingly, Kaspar clearly rejected the implementation of formal sentencing guidelines in his expert opinion, ${ }^{221}$ and the overwhelming majority at the seventy-second Conference of the Association of German Jurists followed him in this regard. ${ }^{222}$ However, this result is not surprising given that the expert opinion only focused on the internally flawed U.S. Federal Sentencing Guidelines. ${ }^{223}$ Narrative-based sentencing guidelines, like those operating in England and Wales, nevertheless, are inherently more flexible and, therefore, far more suitable as a model that German law reform could follow.

Some degree of flexibility is also necessary from a constitutional perspective. As some authors have noted, strictly binding sentencing guidelines or rigid sentencing schemes would violate the German Constitution. ${ }^{224}$ Moreover, mandatory sentencing guidelines would contradict the role and self-conception of German judges. ${ }^{225}$ Thus, it is unlikely that the German judiciary would accept a rigid sentencing guidelines regime.

However, the fact that there might be some reluctance towards formal sentencing guidelines among German judges does not, and should not, represent an impediment to reform. It is understandable that an old system may be perceived as more comfortable and that getting accustomed to a new system will require some effort. ${ }^{226}$ Therefore, ensuring acceptance among the judiciary will be crucial. As Tom O’Malley has put it: "If sentencing guidelines are to succeed, they must engage hearts as well as minds - and if not at the outset, then at least over time."227

\section{E. Concluding Remarks}

In striving for greater consistency, Germany will have some way to go. As this Article has argued, what lies ahead is a reform that should include three steps: A reform of the current sentencing framework, improvements to the lack of sentencing data, and the implementation of a narrativebased, flexible sentencing guidelines regime. Although these steps-especially the implementation of a sentencing information system and the creation of a sentencing advisory body-will require financial resources, this Article has shown that these endeavors are worth it because they are likely to achieve a more consistent and predictable sentencing practice, without neglecting the value of individualized justice.

In the meantime, German judges should receive specific training and education. This is certainly not a "quick fix" of the issue, but at least a good start-especially as sentencing is not part of German law students' ordinary judicial curriculum. A suitable forum for professional education could be the German Judges Academy (Deutsche Richterakademie), with its conference centers in

\footnotetext{
${ }^{220}$ See infra subsection C(II)(4).

${ }^{221}$ KASPAR, supra note 24 , at 82.

${ }^{222}$ See StÄndige Deputation DEs Deutschen Juristentages, supra note 216, at M 189. Out of seventy-two participants at the final vote, sixty-nine voted against formal sentencing guidelines.

${ }^{223}$ See Grosse-Wilde, supra note 24, at 131.

${ }^{224}$ See Jörg Frick \& Philipp Wissmann, Strafzumessungsüberlegungen im Steuer- und Zollstrafrecht: Das ewige Ärgernis, 7 Neue Zeitschrift Für WirTschafts-, Steuer- Und UnTernehmensstrafrecht 438, 440 (2018); Streng, supra note 59, at 154.

${ }^{225}$ See Streng, supra note 59, at 154.

${ }^{226}$ See TONRY, supra note 123, at 171; see also O'Malley, supra note 101, at 229.

${ }^{227}$ O'Malley, supra note 101 , at 229.
} 
Trier and Wustrau. ${ }^{228}$ However, there are two issues in this regard. First, there is no statutory duty for German judges to participate in further training and education, ${ }^{229}$ and a respective proposal for reform-submitted to the German Federal Parliament (Deutscher Bundestag) by the Green Party (Bündnis 90/Die Grünen) ${ }^{230}$ —was rejected after plenary discussion in May 2020. ${ }^{231}$ Second, the German Federal Audit Office (Bundesrechnungshof) has criticized federal authorities for spending too much money on the German Judges Academy. ${ }^{232}$ However, doubts as to whether judicial training would decrease as a consequence have been dispelled because the German Federal Parliament's Audit Committee (Rechnungsprüfungsausschuss) recently decided not to cut payments in the foreseeable future. ${ }^{233}$ Furthermore, the lack of a statutory duty should not give rise to overly serious concerns because voluntary additional education might even prove more efficient in the end. As German judges value their independence, ${ }^{234}$ they are likely to participate in workshops and training sessions with a completely different mindset if attendance is not compulsory; they might perceive it as a chance for personal development and an opportunity for mutual exchange-at least, this is what can be hoped for.

${ }^{228}$ See Frank Jüttner, Überregionale Fortbildung für Richter und Staatsanwälte an der Deutschen Richterakademie [Supraregional Advanced Training for Judges and Public Prosecutors at the German Judges Academy], 89 DEUTSCHE RICHTERZEITUNG 87 (2011).

${ }^{229}$ See Richterfortbildung in Deutschland [Judge Training in Germany], DeUTSCHER BundestaG, 4 (2016), https://www. bundestag.de/resource/blob/415580/df4c51a09ac344d9ae7cbfa4bf8f4880/WD-7-022-16-pdf-data.pdf.

${ }^{230}$ See Fortbildung von Richterinnen und Richtern sowie Qualitätssicherung im familiengerichtlichen Verfahren [Further Training for Judges and Quality Assurance in Family Court Proceedings], Deutscher BundestaG, Drucksache 19/8568 (Mar. 20, 2019), http://dip21.bundestag.de/dip21/btd/19/085/1908568.pdf. For further details, see Mechthild Dyckmans, Fortbildungspflicht für Richter? [Further Training for Judges?], 86 DEUTSCHE RiCHTERZEITUNG 149 (2008); Klaus Henning and Urban Sandherr, Fortbildungspflicht ins Gesetz? Pro und Contra [Compulsory Training in Law? Pros and Cons], 91 DEUTSCHE RichtERZEITUNG 396 (2013).

${ }^{231}$ See Basisinformationen über den Vorgang [Basic Information About the Process], DIP, http://dipbt.bundestag.de/extrakt/ ba/WP19/2452/245229.html.

${ }^{232}$ Bemerkung Nr. 09: Überhöhte Bundesbeteiligung an der Finanzierung der Deutschen Richterakademie [Comment No. 09: Excessive Federal Participation in the Financing of the German Judicial Academy], BundeSRECHNUNGSHOF (2018), https://www. bundesrechnungshof.de/de/veroeffentlichungen/produkte/bemerkungen-jahresberichte/jahresberichte/2018/langfassungen/ bmjv/2018-bemerkungen-nr-09-ueberhoehte-bundesbeteiligung-an-der-finanzierung-der-deutschen-richterakademie-pdf.

${ }^{233}$ See Finanzierung der Deutschen Richterakademie Gesichert [Financing of the German Judges' Academy Secured] BECKAKtUell (Apr. 7 2020), https://rsw.beck.de/aktuell/daily/meldung/detail/finanzierung-der-deutschen-richterakademiegesichert.

${ }^{234}$ In this regard, see THORSTEN BERNDT, RICHTERBILDER 243 (2010).

Cite this article: Herz C (2020). Striving for Consistency: Why German Sentencing Needs Reform. German Law Journal 21, 1625-1648. https://doi.org/10.1017/glj.2020.90 